\title{
PALM OIL AND PALM KERNEL OIL: VERSATILE INGREDIENTS FOR FOOD APPLICATIONS
}

\author{
NOOR LIDA HABI MAT DIAN*; RAFIDAH ABD HAMID*; SIVARUBY KANAGARATNAM*; \\ WAN ROSNANI AWG ISA*; NORAZURA AILA MOHD HASSIM*; NUR HAQIM ISMAIL*; \\ ZALIHA OMAR* and MISKANDAR MAT SAHRI ${ }^{*}$
}

\begin{abstract}
About $80 \%$ of the palm oil (PO), palm kernel oil (PKO) and their fractions produced globally are used for edible purposes. The unique solid content profile of $P O$, and its excellent oxidative stability, high nutritional value (free of trans fatty acids and cholesterols, and rich in micronutrients), and competitive price makes $P O$ as one of the most utilised oils by food manufacturers. Being naturally semi-solid and stabilises in $\beta^{\prime}$ polymorphic form which is required for good creaming and baking performances, $P O$ is an excellent choice for the manufacture of cooking and baking fats such as margarine, shortenings and vanaspati. PKO which is derived from the flesh of the oil palm fruits' kernel is high in lauric acid and has a sharp melting, a character suitable for use in confectionery fats. Fractionation of PO into palm stearin (POs) and palm olein (POo), and PKO into palm kernel stearin (PKOs) and palm kernel olein (PKOo) further enhances the usage of PO and $P K O$ in foods. $P O$ and $P O o$, due to their high content of oleic acid and natural antioxidant (vitamin E) have excellent oxidative stability, hence, are a superior cooking and frying oil. POs which is available in a wide range of saturation level serves as a good hardstock for trans-free solid fat product formulations. Blending of POs with PKO or PKOo and liquid oils such as super POo, sunflower or soyabean oil produces solid fat products such as bakery margarine/shortening, table margarine/spreads, pastry/laminating fats of excellent functional, textural and storage properties.

Interesterification further enhances the usage of palm products especially the hard POs. The hard POs can be interesterified with PKO or PKOo to produce hardstock that can be blended with liquid oils to get stable texturised solid fats of excellent consistency and low saturates content. PKOs and palm mid fraction are widely used as confectionery fats. PO, PKO and their products are also used in the manufacture of dairy, meat and coconut milk product analogs. Apart from its main usage as frying/cooking oil, POo can be used as salad oil. In their powdered form, PO, PKO and their fractions can be used in multiple application in convenience food preparation. Development of functional food or nutraceutical products from palm micronutrients such as tocotrienol-rich fraction, carotene, squalene and co-enzyme Q10 is also an in-thing. Utilisation of the high technology processes would further enhance the nutrition and health benefits, and applications of $P O$ and its micronutrients in the food industry.
\end{abstract}

\section{Keywords: palm oil, palm kernel oil, palm stearin, palm olein, trans-free, food applications.}

Malaysian Palm Oil Board,

6 Persiaran Institusi, Bandar Baru Bangi,

43000 Kajang, Selangor, Malaysia.

E-mail: nlida@mpob.gov.my 


\section{INTRODUCTION}

Palm oil (PO) is derived from the mesocarp of oil palm fruits, and has a balance unsaturated (mainly oleic) and saturated (mainly palmitic) fatty acids. PO is an economically important and versatile vegetable oil used as a raw material for both food and non-food products, and is the most widely used vegetable oil in the world (Zion Market Research, 2017). It has been used in a myriad of food applications and preparation for thousands of years. About $80 \%$ of PO products are used for edible application (Basiron, 2007). PO share in food use has grown to $32.5 \%$ in 2013 and will exceed $34 \%$ in the near future (Basiron, 2015). Not only because of its competitive price, the distinctive quality of $\mathrm{PO}$ such as its natural excellent oxidative stability, unique solid content profile, high nutritional value, free of trans fatty acids and cholesterols, antioxidant properties and non-genetically modified makes $\mathrm{PO}$ as one of the most utilised oils by food manufacturers (Choo, 2013). PO has an excellent oxidative stability as it is high in monounsaturated fatty acid (oleic acid) and vitamin $\mathrm{E}$, and low in polyunsaturated fatty acid. Hence, food products produced or processed using PO have a relatively long shelf-life with a low degree of rancidity. Owing to its semi-solid in nature, PO does not require hydrogenation, a process to increase the saturated fatty acid content of liquid oil that produces trans fatty acids, prior to be used in food formulations. This is particularly important to food industry following the requirement of trans fatty acids labelling by the United States Food and Drug Administration in 2003 (Tarrago-Trani et al., 2006). There is an increasing concern on the presence of trans fatty acids in hydrogenated products, due to its bad adverse effect on cardiovascular health. As for vegetable oils such as corn oil, soyabean oil, cottonseed oil and canola oil, hydrogenation is a prerequisite to achieving oxidative stability and solid fat content (SFC) similar to PO.

The awareness among consumers of the detrimental health effects of consuming foods with trans fatty acid from partially hydrogenated oils has created greater demand for food formulated or prepared using natural oils and fats or oils and fats that are free of trans fatty acids (O'Brien and Wakelyn, 2005). Hence, PO and its fractions which are free of trans fatty acids are the best solutions and option to replace the use of partially hydrogenated fats in foods formulation and processing. Advancement in fractionation technology has made possible to produce a wide range of hard palm fraction (palm stearin, POs) with iodine value (IV) as low as less than 10. Such hard fats would be useful in margarine and shortening formulations as they can be used as a texturiser to totally replace the trans fats. Furthermore, PO is similar to animal fats such as tallow and lards in terms of physical properties.
Thus is a good alternative to replace the use of the animal fats in meat products such as sausages and meat patties (O’Brien, 2009).

Palm kernel oil (PKO) is abtained from the kernel of the oil palm fruits. Its composition and properties differ significantly from PO. PKO is high in lauric acid and has a sharp melting profile; thus it is suitable for confectioneries and other specialty fats.

This article reviews the use of $\mathrm{PO}, \mathrm{PKO}$ and their fractions in a myriad of food applications and preparation.

\section{FRYING/COOKING OIL}

Frying is a traditional and most popular method of cooking throughout the world. This process involves immersing food in heated oil at a temperature of $150^{\circ} \mathrm{C}$ to $180^{\circ} \mathrm{C}$. During this process, many undesirable reactions occur that cause the deterioration of the frying medium. These processes are mainly hydrolysis, thermal oxidation and polymerisation (Setyawan et al., 2013). Hence, selection of frying medium is crucial in frying process as it can affect the quality of the fried foods as well as the health of the consumers. Vegetable oils, animal fats or a mixture of both can serve as the frying medium. In order to select the frying medium suitable for deep-frying, the important attributes to be considered are the ability of the fats / oils to withstand the high temperature of deepfrying as well as stable against the oxidation and polymerisation. The oil must have a high resistance to oxidation and gumming, low free fatty acid rise and smoking, low rate of foaming, low rate of darkening, low melting point (except for special purpose) and nutritionally good fatty acid composition (Nor Aini and Miskandar, 2007a; MPOB, 2014). The levels of saturated-unsaturated fatty acids in fats/oils determine the stability of the frying medium against the oxidation. Fats and oils that contain high level of saturated fatty acids such as animal fats offer high temperature and oxidative stability. However, these types of fats and oils are not preferred due to the health concerns of the consumption of cholesterol and high saturated fatty acids. Meanwhile, fats and oils that contain high levels of unsaturated fatty acids such as sunflower oil, soyabean oil and canola oil are susceptible to oxidation and produced the undesirable smell and toxic compounds due to the breakdown of unsaturated fatty acids to di- and monoacylglycerols, glycerol, and free fatty acids.

PO and especially its liquid fraction palm olein (POo) are widely used for frying than any other purposes, for both performance and economic reasons, and are always regarded as an ideal and heavy-duty frying oil (Nallusamy, 2006). POo is the most popular and extensively used frying oil in 
the food industry (Matthaus, 2007). Products fried in $\mathrm{PO}$ and $\mathrm{POo}$ include potato chips, French fries, doughnuts, ramen noodles, fritters and nuts. PO and POo have good resistance to thermal oxidation at prolonged elevated temperatures due to their inherent composition. Their longer frying life, less tendency to foam and polymerise make them a better frying oil than liquid oils such as corn and soyabean oil. The excellent oxidative and prolonged heat stability of $\mathrm{PO}$ and $\mathrm{PO}$ are due to their fatty acid composition and micronutrient content. PO and POo are high in oleic acid and contain only traces of the unstable linolenic acid and a moderate amount of linoleic acid (Augustine et al., 1988). PO's natural antioxidants, namely tocopherols and tocotrienols, offer an outstanding oxidative stability to $\mathrm{PO}$ and $\mathrm{POs}$, thus making $\mathrm{PO}$ and $\mathrm{PO}$ to have a prolonged shelf-life (Edem, 2002). PO contains $800-1270 \mathrm{mg} \mathrm{kg}^{-1}$ vitamin E (Puah et al., 2007; Choo et al., 2004;1997), which further comprises of about $20 \%$ tocopherol $(\alpha-\mathrm{T})$ and $80 \%$ tocotrienols $(22 \% \alpha$-, $46 \% \gamma$ - and $12 \% \delta$-tocotrienol) (Hashimoto et al., 1980). Another promising attribute of $\mathrm{PO}$ and $\mathrm{POo}$ as a frying oil is that they impart longer shelf-life to the fried products, do not give rise to unpleasant room odour and do not polymerise to gums, due to the presence of comfortable level of unsaturation and natural antioxidants together with the absence of linolenic acid (MPOB, 2014). Studies by Matthaus (2007), Bracco et al. (1981) and Faur (1975) indicated that $\mathrm{PO}$ and $\mathrm{POo}$ have similar frying performance compared with other high-stability oils.

Tarmizi and Ismail (2008) demonstrated that frying stability of standard POo was comparable to special quality $\mathrm{POo}$, and for use in the industrial production of snack foods. Standard POo is graded with maximum free fatty acids of $0.1 \%$ and peroxide value of 2-4 mequiv $\mathrm{O}_{2} \mathrm{~kg}^{-1}$. The special quality $\mathrm{POo}$ is a superior quality POo produced under stringent quality assurance from harvesting until refining with free fatty acid and peroxide value of less than $0.05 \%$ and 1 mequiv $\mathrm{O}_{2} \mathrm{~kg}^{-1}$, respectively. Special quality $\mathrm{POo}$ is traded at a premium price of about USD 50 per tonnes (FOB Bulk) higher than that of standard POo. A study on the comparison of the stability of animal fats and highly unsaturated oils towards oxidation by Zeddelmann and Wurziger (1973) showed that PO and partially hydrogenated groundnut oil were the most stable oils against oxidation at high temperature. Another study by Siddique et al. (2010) compare the physico-chemical properties of blends of $\mathrm{POo}$ with other vegetable oils, proved that POo was the most stable against oxidation rancidity among soyabean, sunflower (SFO) and canola oils. Abdulkarim et al. (2007) compared the frying quality and stability of high oleic Moringa oleifera seed oil with other vegetable oils which included POo, canola oil and soyabean oil, and found that POo and Moringa oleifera seed oil had a longer induction period and it indicated that they were less susceptible to oxidation than canola oil and soyabean oil.

Utilisation of POo as frying/cooking oil can be further extended by blending with other liquid vegetable oils. Blending helps to cater for a certain segment of the market which has a preference for a particular flavour. For example, blends of POo with groundnut and/or sesame oils are very popular among the Chinese and Indian housewives. Studies have shown that blending of POo with liquid vegetable oil improve POo clarity and partial crystallisation at low-temperature storage, thus making POo suitable to be used in temperate countries (Siddique et al., 2010; Basoglu et al., 1996; Mahmoud et al., 1996; Nor Aini et al., 1992). Blending has a similar effect to partial hydrogenation in reducing the linoleic and linolenic acid contents of liquid vegetable oils without introducing trans isomers of fatty acids. A blend of $\mathrm{POo}$ and liquid vegetable oils such as groundnut oil, cottonseed oil and soyabean oil enhances the stability of the liquid vegetable oils (MPOB, 2014). Tarmizi and Ismail (2014) demonstrated that blending of PO with unsaturated oils was generally proved to keep most qualitative parameters comparable to those demonstrated in PO. Indeed, none of the oils surpassed the legislative limits for use in frying. Overall, it was noted that oil containing PO and SFO showed higher resistance toward oxidative and hydrolytic behaviours as compared to the other oil blends. De Marco et al. (2007) found that blend of $\mathrm{PO}$ and SFO proved to keep qualitative parameters (free acidity, spectrophotometric indices, total polar components, fatty acid composition, short-chain fatty acids, tocopherol and tocotrienol content and composition, colour, flavour evaluated by means of an electronic nose) comparable to those shown by $\mathrm{PO}$ during a prolonged $(8 \mathrm{hr}$ discontinuous frying without oil replenishment) frying process. Leonardis and Macciola (2012) reported that thermal stability of virgin olive oil greatly increased when blended with PO. A study by Roiaini et al. (2015) showed that canola and olive oils blend at a ratio of 80\%:20\% had the best physico-chemical properties after addition of $20 \%$ PO. The study showed that the tocopherols and tocotrienols in $\mathrm{PO}$ were most stable in the blend of $\mathrm{PO}$ and canola oil as compared to PO alone during deep fat frying. Omar et al. (2014) found that the addition of a small proportion of virgin coconut oil in palm-based shortening would improve the frying performance of oil as well as sensory scores of the fried products.

One of the most objective and valid criteria for the evaluation of deterioration in oils and fats is the formation of polar compounds. The content of total polar compounds is the most predominant indicator for oil quality and is widely used in many international regulations (Firestone, 2007; 
Fritch, 1981). For public health concerns, the content of total polar compounds and acid value in frying oil are regulated at not more than 25\% (Lee, 2009). Polar compounds increase during frying as a result of oxidation of fatty acids. The level of polar compounds reflects the amount of degraded products formed during heating and frying. Polar compounds include among others polymers, monoglycerides, diglycerides and cyclic compounds. Cyclic components are much more harmful to health than other components of polar compounds (Nor Aini et al., 2002).

Razali (2005) reported on the frying performances of $\mathrm{PO}$ and $\mathrm{PO}$ in three major applications, i.e., industrial production of potato chips/crisps, industrial production of pre-fried frozen French fries and in fast food outlets. Study on the performance of POo in industrial production of potato chips / crisps (potato chips were continuously fried $8 \mathrm{hr}$ a day and five days a week) showed that POo performed well and was still in excellent condition and usable at the end of the trial. This was reflected in low polar and polymer contents of $10 \%$ and $2 \%$, respectively, and high content of tocopherols and tocotrienols of 530 ppm even after $>1900 \mathrm{hr}$ of frying. Study on the performance of PO in industrial production of pre-fried frozen French fries (the industrial frying was continuously done for 12 days), showed that PO performed excellently as reflected by its low polar and polymer contents of $17 \%$ and $2.8 \%$, respectively, over the 12 days of trial. Study on the intermittent frying of chicken parts using palm shortening, $\mathrm{PO}$ and $\mathrm{PO}$ in the laboratory simulating the conditions in fast food outlets showed that the three palm-based frying oils performed very satisfactorily, as reflected by their reasonably low polar and polymer contents of $<25 \%$ and $<6 \%$, respectively, after five days of consecutive frying. All the quality indicators did not exceed the maximum discard points for frying oils / fats in the three applications. The findings by Razali (2005) are coherent with findings by Chen et al. (2013) and Omar et al. (2007). Chen et al. (2013) reported that the rate of total polar compounds generation in POo was slower than that in soyabean oil during frying. Study by Omar et al. (2007) showed that PO solid frying fat which has a melting point of about $42^{\circ} \mathrm{C}$ (to facilitate processing and so that it is stable during transportation and on the supermarket shelf), showed to have polar content development significantly lower than an imported hydrogenated frying fat, and smoke point of only $220^{\circ} \mathrm{C}$ after five days of continuous frying on a standard frying method.

\section{STRUCTURED FATS}

Saturated fats and trans fat are the main structuring agent in contributing to the texture of solid fats systems. The pressure to reduce saturated fat intake and eliminate trans fats from our diets has made structuring liquid oils an active area of research in the past decade. Solid fat (hard stock) provides structure in numerous food products contributing to hardness, mouthfeel and solidlike behaviour. They are responsible for network structure. Thus, it is often difficult or impossible to eliminate this ingredient to improve the health aspects of the product, without sacrificing some of the characteristic properties. For example, the triacylglycerol (TAG) profile is responsible for the narrow melting range of chocolate and the broad melting profile of margarine (Pernetti et al., 2007; Rogers, 2009).

Saturated TAG are used as structural fats to develop a wider range of structuring agent in high fat food or solid fat formulations such as margarine and shortening (Omonov et al., 2010). Traditionally, solid fat in high-fat food formulations is obtained by hydrogenation of liquid oils. Hydrogenation results in the formation of trans fatty acids where some cis double bonds are rearranged to trans bonds (Fomuso and Akoh, 2001; List et al., 1977). Several studies have suggested a direct relationship between trans fatty acids and increased risk of coronary heart diseases as well as rise of plasmatic lipid levels. There are also suggestions that the negative consequences of trans fatty acids consumption go beyond the cardiovascular risk (Wang et al., 2016). There are scientific consensus that trans fatty acids specifically increase the risk of other chronic health problems such as cancer (Chavarro et al., 2008), diabetes (van-Dam et al., 2002; Hu et al., 2001), obesity (Gosline, 2006) and infertility (Chavarro et al., 2007). Due to their high solid fat content at ambient temperature that contributes to structural stability, high oxidative stability (long shelf-life), cost-effective price and availability, PO and its hard fraction, POs of various IV or level of saturation have been widely used to replace hydrogenated lipids in the high-fat food or solid fat formulations (Pande and Akoh, 2013; Lai et al., 2000). PO and POs can be blended and interesterified with liquid oils in order to enhance the physical characteristics of the mixture to meet the functional properties and the quality required for high-fat food or solid fat formulations (Sellami et al., 2008). POs with specific and tailor-made modification techniques can deliver excellent texture from the point of view of good structuring ability and ensure good mouthfeel of the final product (Pande and Akoh, 2013). Combination of the solid POs with liquid oils such as soyabean, sunfiower, canola and pine oils, and lauric fats such as coconut oil and $\mathrm{PKO}$ provide fat blends of suitable SFC and melting profiles for solid fat formulations (Noor Lida et al., 2007; Foglia et al., 1993).

Interesterification is a reaction involving acyl groups interchange between esters, normally TAG. 
It is used to change the positional distribution of fatty acids in the TAG molecules and thus alter the physico-chemical properties of individual fats and oils or their blends. There is no formation of trans fatty acids upon interesterification. Interesterified fats are widely used as textural fats for solid fat formulations (Ruan et al., 2014; Adhikari and $\mathrm{Hu}$, 2012; Soares et al., 2012; 2009; Adhikari et al., 2010), to replace partially hydrogenated fats which are loaded with trans fatty acids (Nor Aini and Noor Lida, 2005). POs promotes the formation of desirable plastic fats when it is interesterified with vegetable oils (Jeung et al., 2008). POs blended with a lauric fats such as PKO and coconut oil showed substantial improvement in the melting and crystallisation properties, which provided better functional properties such as ease of handling and mouthfeel (Noor Lida et al., 2007). Enzymatic interesterification of POs, lauric fats (e.g., PKO, or coconut oil) and liquid vegetable oils produce trans-free interesterified fats that have more tendency to crystallise and stabilise in $\beta^{\prime}$ crystals, lower slip melting point and lower SFC at $10^{\circ} \mathrm{C}-15^{\circ} \mathrm{C}$ than the original blend (Ruan et al., 2014; Zhang et al., 2004; Chu et al., 2002). Interesterified POs and soyabean oil blends show desirable characteristics suited for the production of the trans-free soft tub, stick and bakery margarine, allpurpose shortening and Iranian vanaspati (Naeli et al., 2017). Interesterified POs and SFO blends show desirable characteristics for table margarine (Lai et al., 1998a, b). Ghosh and Bhattachcharyya (1997) reported that interesterification of POs (melting point of $58^{\circ} \mathrm{C}$ ) blended with liquid oil such as SFO, soyabean and rice bran oils were suitable for use as trans fatty acid-free and polyunsaturated fatty acid-rich shortening and margarine fat base. Interesterification of POs, extra virgin olive oil and fully hydrogenated soyabean oil at different ratios produce fats which are suitable for the bakery industry (Jeung et al., 2008). Trans-free fats containing nervonic acid, a fatty acid with beneficial effects for mental health are prepared by interesterification of POs, Acer truncatum oil and PKO to facilitate the adaption of nervonic acid into the food system ( $\mathrm{Hu}$ et al., 2017).

Medium- and long-chain triacylglycerol (MLCT) is a type of modified lipid and consists of both medium-chain fatty acid and long-chain fatty acid attached to its glycerol backbone. MLCT is metabolised differently compared to conventional fats and oils which can lead to a reduction of fat accumulation in the body. It is increasingly popular because of its anti-obesity ability, and therefore it is considered as a healthy functional fat (Xu et al., 2016; Lee et al., 2012). The MLCT fats can be produced by interesterification of shea olein and palm kernel stearin (PKOs) in 40\%:60\% ratio (Xu et al., 2016) and PKO and PO in 90\%:10\% ratio (Lee et al., 2015).

\section{MARGARINES}

Margarine is a water-in-fat emulsion. Margarine can be classified into two major categories which are table margarine (having medium plastic and soft margarine characteristics) and bakery margarine (having medium and hard plastic margarine characteristics). Table margarines which come in tub or packet, are further categorised into two types, i.e., refrigerated and non-refrigerated. Nonetheless, both categories are stable and spreadable at room temperature. Bakery margarine, on the other hand, has a wide plasticity range and must have sufficient solid at usage temperature. This allows such margarine to be used in cakes, bread, cookies, pastries and other bakery products. While such products are usually made from shortening, similar functionalities are provided by bakery margarine. Thus, both products could be used together within a certain amount (Nor Aini and Miskandar, 2007b).

Fat crystallisation, types of oils and fats used in the formulation and controlling process operation in the fat food industry are crucial in order to produce margarine products of desired quality (Sellami et al., 2012; Himawan et al., 2006; Metin and Hartel, 1998; Walstra, 1998). Hydrogenated liquid vegetable oils had been widely used as hard stock for good margarine shortening consistency since the introduction of hydrogenation technology in the early nineteenth century (O'Brien, 2008). However, partial hydrogenation could result in the formation of trans fatty acid which has an adverse health effect as discussed earlier. The increase in consumer awareness on trans fatty acids issue has encouraged researchers and food manufacturers to carry out extensive studies on nutritional as well as functional benefits of PO and its fractions, in replacing hydrogenated liquid oils.

As trans-free margarine is currently a requirement in many countries, $\mathrm{PO}$ which is naturally semi-solid and palm hard fraction (POs) are among the preference as they are naturally solid. PO also becomes the choice for trans-free margarine formulations due to its content of equal quantities of saturated and unsaturated fatty acids. This is important as far as polymorphic stability is concerned. PO and POs are normally blended with PKO or palm kernel olein (PKOo) which improve the SFC profile and $\beta^{\prime}$ stability of the margarine. Thus, $\mathrm{PO}$ and POs, are becoming important raw materials and choice for food industry in producing plastic fats such as palm-based margarine and shortening (Oliveira et al., 2015; Miskandar and Zaliha, 2014; De Clercq et al., 2012; Liu et al., 2010; Parveen, 2000). The presence of trans fats in solid fat products formulation such as margarine and shortening could best be eliminated by using POo and soyabean oil as useful source of liquid oils 
while POs as hard stock (Pande and Akoh, 2013; Sellami et al., 2012).

Firmness, spreadability, smoothness and proper melt-down are the key textural characteristics of the margarine product, and these characteristics are influenced by the solid-liquid-fat ratio as a function of temperature (Szczesniak, 1997). Crystal polymorph plays another important key role in the final product's consistency and acceptability. In shortenings and margarine, $\beta^{\prime}$ is the desired crystal form because $\beta^{\prime}$ crystals are desirably small and could result in smooth texture and provide desirable functionality. On the other hand, $\beta$ form tends to give rise to large crystal size and aggregating into grainy textured products. The development of grainy texture in solid fat formulations, especially margarine, is due to the transformation of $\beta^{\prime}$ to $\beta$ polymorph (Zaliha et al., 2015a, b; Garima and Akoh, 2013; Ward, 1998). As margarine should be at a complete melt in the mouth, the temperature of $37^{\circ} \mathrm{C}$ (body temperature) is typically used as a reference for formulating table margarine. SFC of $28 \%$ at $15^{\circ} \mathrm{C}$ and $12 \%-15 \%$ at $20^{\circ} \mathrm{C}$ are common for table margarine in order to aid packing process as well as to abstain from oiling out (Miskandar and Nor Aini, 2010).

Nor Aini and Miskandar (2007a) reported that 25\% PO content in margarine is trivial. Although $\mathrm{PO}$ content in a table margarine formulation can be up to $50 \%$, margarine meltability can be affected. POs with various IV has gained popularity as an alternative to partially hydrogenated or trans fat (MPOB, 2017). POs at 10\%-15\% can be blended with soft oil to produce tub margarine (Nor Aini and Miskandar, 2007b). Non-refrigerated table margarine is referred to can margarine which is commonly used as general-purpose margarine which should have sufficiently broad plasticity range (Miskandar et al., 2005).

Bakery margarine does not require refrigeration and therefore, could tolerate dough working condition. Palm fractions of 50\%-100\% could be used to formulate cake margarine. $\mathrm{PO}$ which is well-known for its high palmitic acid level could aerate fat and sugar mixtures well. PKO is also a suitable raw material for this product as it imparts fast crystallisation which result to great creaming properties for cake. Other than cake margarine, palm fractions especially POs are used to produce pastry margarine. High SFC is required to obtain good plasticity to survive numerous layering process of pastry making (Nor Aini and Miskandar, 2007b). Blend of $\mathrm{PO}, \mathrm{POs}$ and $\mathrm{PKO}$ is suitable to prepare pastry margarine and is comparable to commercial pastry margarine when high POs content is used (POs IV 40 of more than $50 \%$ or POs IV 32 of more than 30\%) (Noor Lida et al., 1996a). Suitable fats for margarine could also be achieved through the interesterification of palm fractions. Lai et al. (1999) found that interesterified POs/SFO 40\%:60\% and 50\%:50\% ratios are suitable for table margarine production. Adhikari et al. (2010) reported that fat from the enzymatically interesterified POs, coconut oil and rice bran produced suitable blend for margarine having SFC of $15.5 \%-34.2 \%$ at $25^{\circ} \mathrm{C}$, slip melting point of between $27.5^{\circ} \mathrm{C}-34.3^{\circ} \mathrm{C}$ and with $\beta^{\prime}$ polymorphism dominant. Noor Lida et al., (2016a, $\mathrm{b}, \mathrm{c})$ found that interesterified palm mid fraction (PMF) excellently performed as bakery margarine, better than the performance of commercial bakery margarine which was made of $\mathrm{PO} / \mathrm{PKO}$ blend. The interesterified PMF also performed well in table margarine formulation.

Processing is another crucial determinant of margarine quality apart from suitable formulation for a desired property. During processing, which mainly involves crystallisation, a cooling condition applied that does not lead to the thermodynamic equilibrium between the composition of the solid and the liquid phases could result in recrystallisation. Recrystallisation usually occurs during transportation and retail, and could develop a new solid phase (Hishamudin et al., 2011; Smith et al., 1994) that could result in an inferior product. Crystal growth, as a result of recrystallisation, leads to the formation of solid bridges (sintering) between the narrow gaps of the crystal networks upon storage (Johansson et al., 1995). A proper margarine processing method would improve the sensory and physical characteristics of margarine products (Miskandar et al., 2005). Proper processing condition with proper selection of fat blends would also hinder post-crystallisation problem in margarine made of palm-based fats. Post-crystallisation in palm-based margarine and shortenings is a general quality issue that is associated with their slow crystallisation behaviour hence in some cases leads to processing difficulties (Duns, 1985). This phenomenon increases the hardness of finished products several weeks after production and has limited the maximum usage of palm fractions in soft margarine (Nor Aini and Miskandar, 2007a). Post-crystallisation of PO/ SFO soft margarine formulation has been minimised by optimising the processing conditions (Miskandar and Zaliha, 2014). A relatively high-speed pinrotor unit coupled with a homogeniser operated at optimum pressure could enhance the completion of crystallisation activities during processing and improves the product quality.

\section{REDUCED FAT SPREADS}

Reduced fat spread which normally contains $40 \%$ $60 \%$ fats, can be formulated for convenience and health. The oil or fat phase has a major influence on the shape, size, and arrangement of the crystals network, which in turn, determines the melting characteristics of the products and provides the 
forms and texture of the finished spreads (Charteris and Keogh, 1991). PO, PKO, and their fractions are important fats in reduced fat spread formulations, mainly from an economic standpoint, nutrition and product performance and characteristics. Blends of $\mathrm{PO}$ and $\mathrm{SFO}$ in 50\%:50\% ratio can be used to formulate tub type reduced fat spread. Blends of $70 \%-75 \%$ PO, $24 \%-30 \%$ SFO and 0\%-6\% PKOo are suitable for block type reduced fat spreads. Blends consisting of $16 \%-23 \%$ POs IV40, $60 \%-80 \%$ SFO and 0\%-23\% PKOo are also suitable for tub reduced fat spread. Interesterified blends consisting as high as $66 \%-76 \%$ POo IV 60, 24\%-30\% SFO and 0\%-8\% PKOo are recommended for tub reduced fat spread and $78 \%-98 \%$ POo IV 60, 2\%-12\% SFO and 0\%$18 \%$ PKOo are recommended for block reduced fat spread (Noor Lida and Md Ali, 1998).

\section{SHORTENINGS}

Shortenings is a visco-elastic semi-solid food product containing both liquid and solid fats. The liquid is entrapped in between the network of crystals. Being semi-solid, PO is a useful and convenient ingredient for shortening formulations since it is naturally semi-solid at ambient temperature. An important role of $\mathrm{PO}$ and palm fractions in shortenings is to provide consistency, texture and structure to the products without the need for hydrogenation (Nor Aini and Miskandar, 2007a). In formulating a consistent fat such as shortening, a common method is to match the SFC profile for compatible physical characteristics. Bakery shortenings generally have a flat SFC profile. A good bakery shortenings should have $15 \%-25 \%$ solid fat at $20^{\circ} \mathrm{C}$ and melting point of $>38^{\circ} \mathrm{C}$. However, even if the SFC and the melting points of two different shortenings are similar, their performance in baked products can still be affected by their structural and compositional differences. $\mathrm{PO}$ with SFC of about $22 \%-25 \%$ at $20^{\circ} \mathrm{C}$ shows a consistency similar to that in a plastic cake shortening. However, a shortening based on 100\% PO performs poorly in cakes, as the cakes do not hold sufficient air during preparation that leads to low volume. The performance of PO-based shortening, however, can be improved by the addition of PKO. The amount of $\mathrm{PO}$ is generally $30 \%-40 \%$, but exceptionally up to $80 \%$, in shortenings. With the right selection of emulsifiers, shortenings based on 100\% PO with good performance could be produced. POs of various IV could also be used in formulating shortening of excellent performance. POs of low IV, such as IV 14, tends to stabilise shortenings in the $\beta$ form for them to perform effectively in cakes. Blending of palm products with other commercial oils and fats could also produce shortenings that perform well and comparable to the performance of commercial shortenings which are made of partially hydrogenated liquid oils (Reshma et al., 2008; Berger and Nor Aini, 2005; Nor Aini et al., 1989; Duns, 1985).

Excellent performance of palm-based shortening has been proven by many other studies. Sciarini et al. (2013) who studied the effect of lauric-based shortening with varying SFC made from different ratios of high oleic SFO, PKO and hard POs on the properties of dough and sugar-snap biscuits found that shortening with 20\%-25\% SFC produced the best quality biscuits. Furthermore, Nor Aini and Miskandar (2007a) found that the textural characteristics of rolled biscuits made from $100 \%$ PO were quite similar with those made from $100 \%$ butterfat. Both biscuits received almost similar scores in the sensory evaluation except for crispiness. Ramli et al. (2008a) who studied the performance of shortenings prepared from palm products in pound cake concluded that palm-based high oleic cake shortening received a high score in flavour, texture and eating quality. Mayamol et al. (2004) formulated shortening consisting of POs and rice bran oil blends contain primarily the most stable $\beta^{\prime}$ form, suitable for cake making. Chin et al. (2010) who studied the effect of palm-based shortening with various melting points on the quality of the bread, found that bread incorporated with palm-based shortening had good volume and oven spring. Palm-based shortening could also enhance the quality of nongluten bread as reported by Aguilar et al. (2015), Demirkesen et al. (2013), Miñarro et al. (2012), Sciarini et al. (2012) and Schober (2009). A study by Yanty et al. (2017) concluded that shortening containing blended palm oil, POs, soyabean oil, fat at various combinations of fat blend and ratios gave similar characteristics to lard shortening. This study found that plant oil-based shortening and lard shortening were similar with respect to their consistency, hardness, compression and adhesiveness values.

Fluid shortening is a suspension of hard fats, emulsifiers and additives, or combinations in liquid oils formulated to be pourable, or pumpable, at room temperature and stable over the temperature range of $15.6^{\circ} \mathrm{C}-32.2^{\circ} \mathrm{C}(\mathrm{O}$ 'Brien, 2004; Ghotra et al., 2002). In Malaysia, the product should be stable at room temperature, i.e., at $25^{\circ} \mathrm{C}-30^{\circ} \mathrm{C}$ (Miskandar et al., 2006). Fluid shortenings are milky-white or opaque in appearance due to suspended solid fat in the liquid oil. Thus, the product should be in a stable form before packaging to avoid any solidification in the package (O'Brien, 2004; Weiss, 1983). The suspended solids causing the opacity is normally from hard fats, as in frying shortening, and from the emulsifiers, as in baking shortening. Monoacylglycerols and propylene glycol monostearate are the most common emulsifiers in fluid shortening formulations. The amount of hard 
material that may be added to the base oil depends on the solubility of that material to make a solid/ liquid suspension of 5\%-30\% solid (Miskandar et al., 2004; Bockisch, 1997).

\section{VANASPATI}

Vanaspati is the Indian name for a hydrogenated vegetable fat used as a substitute for butterfat (ghee) in cooking. In some countries, it is also called 'vegetable ghee' (Kheiri, 1985). It is an important food item in India and Pakistan but is also popular in the eastern Mediterranean countries and known by various names, in Yugoslavia, Greece (voutyros), Turkey, Algeria, Morocco (smin) and others. The absence of moisture makes it more resistant to microbiological deterioration. As vanaspati is produced as a substitute for butterfat which exhibits slow crystallisation to result in a granular texture, this appearance is usually looked upon as a sign of purity and quality (MPOB, 2017).

PO and its solid fraction POs have desirable physical characteristics for vanaspati. Vanaspati can be made with direct blends of PO and POs. Our study indicated that trans-free vanaspati could be produced easily by the direct blending of POs with other liquid oils. To maximise the use of POs, interesterification can be employed. The products obtained simulate conventional partially hydrogenated vanaspati in physical characteristics that include melting point, appearance and consistency. The direct blending of $60 \%$ POs and $40 \%$ liquid vegetable oil produces the most acceptable low melting vanaspati while blending of $80 \%-95 \%$ PO and 5\%-20\% POs (IV 33) could produce vanaspati of $38^{\circ} \mathrm{C}$ melting point. The product appears homogenous, has soft consistency with no oil separation. In the case of interesterified vanaspati, higher amounts of POs of up to $80 \%$ can be incorporated (Nor Aini et al., 1997). Blends of PO, POs and POo in 60\%-80\%:5\%20\%:10\%-15\% ratios, and blends of PO, POs and PKOo in 60\%-80\%/:5\%-20\%:10\%-20\% ratios could also produce vanaspati with similar characteristics to hydrogenated vanaspati (Nor Aini et al., 1999). Low saturates (less than 30\%) trans-free vanaspati based on $100 \%$ palm products can also be produced using hard feedstock from a combination of POs, PKO and PO. The crystallisation curve shows that higher hard feedstock in the formulation will give faster crystallisation in the product.

$\mathrm{PO}$ and its fractions ( $\mathrm{POs}$ and $\mathrm{POo}$ ) can be interesterified with $\mathrm{PKO}$ or other oils to produce granular vanaspati. Example of a good grainy texture vanaspati formulation is interesterified blend of POs and rapeseed oil in 70\%:30\% ratio (MPOB, 2017).

\section{CONFECTIONERY FATS}

PO and PKO are ideal raw materials for confectionery fats because of their unique properties. They can be modified to extend their range of applications. The uses of confectionery fats can be classified into hard and soft chocolates. Applications of $\mathrm{PO}$ and $\mathrm{PKO}$ and their fractions in confectionery fats have been detailed in a review paper by Norazura and Noor Lida (2017).

\section{Hard Chocolate}

Cocoa butter alternatives (CBA) can be classified into three main categories which are the cocoa butter equivalent (CBE), cocoa butter replacer (CBR) and cocoa butter substitute (CBS). Vegetable fat having similar physical and chemical properties as cocoa butter is called CBE. On the other hand, vegetable fats having similar physical properties only as cocoa butter are referred to as CBR (non-lauric-based) and CBS (lauric-based). CBE is compatible with cocoa butter at any ratios. PMF is a source of symmetrical TAG [(primarily 1, 3-dipalmitoy-2-oleoyl glycerol (POP)] and is important in the formulation of a CBE. The PMF with its high content of POP TAG structure could be modified easily either through blending with fractions from exotic fats such as Sal, Shea, Illipe or mango kernel fat or interesterified to produce $\mathrm{CBE}$ of high quality and has all the desirable confectionery fat characteristics (Berger, 1981). Studies by Bootello et al. $(2013 ; 2012)$ have shown that blends of PMF with sunflower hard stearin and high oleic-high stearic sunflower hard stearin are suitable as CBE. Palm mid stearin (IV 45, co-product of the fractionation of POs IV 33 into POs IV 15) has also been reported to be suitable for cocoa butter extender. However, it has limited application (Kellens et al., 2007). The limitation might be due to its poor compatibility with cocoa butter (Pease, 1985). Cocoa butter extender is used mainly to make the confectionery fat more economical (Timms, 2003). CBE can also be produced with sn1,3-specific enzymatic interesterification of PMF and stearic acid (Undurraga et al., 2001) and PO and fully hydrogenated soyabean oil (Abigor et al., 2003).

CBR is less compatible with cocoa butter and is typically used for coating. Currently, low or zero trans-fatty acid CBR is the preference as trans fatty acids are detrimental to health. Low and zero trans CBR can be manufactured from fat similar to CBE but possesses higher asymmetrical disaturated, monounsaturated TAG (SSU) such as PPO, whereby $P$ is palmitic and $O$ is oleic acid which can be achieved, with special fractionation conditions of palm fractions (Smith, 2012). POs and palm mid stearin can also be applied as a hard coating, though the utilisation is limited (Kellens et al., 2007). PKO 
is the main source of palm-based CBS. Examples of CBS are PKOs and hydrogenated PKO. Blend of POs with first and second fractionated palm kernel fat will result in better molding and demoulding properties (Cain et al., 1995). Norizzah et al. (2004) revealed that confectionery fats (non-temper type) having $\beta^{\prime}$-tending polymorph can be produced from POs and PKOo through chemical interesterification. Low-calorie CBS can be obtained through interesterification of PMF, PKOs and medium chain triglycerides oil (Borhan et al., 2011).

\section{Soft Chocolate}

Soft chocolate or chocolate spread is lipid fraction(s) dispersed with fine solids. It is common for chocolate spread to have fat content of between $40 \%-44 \%$. The fat content of between $28 \%-35 \%$ is typically found in the low-fat chocolate spread. Oil separation is one of the important factors to be considered when formulating chocolate spread. Chocolate spread after storage of 6-12 months should not show any development of oil separation for it to be considered as good stability product (Salmi Yati, 2006). Thus, the distinct ratio of solid and liquid is required to develop this product. Blends of $\mathrm{PO}, \mathrm{PO}$, red $\mathrm{PO}$ or POs with other soft oils or butterfat are suitable for chocolate spread (Jeyarani et al., 2015; El-Hadad et al., 2011; El-kalyoubi et al., 2011).

\section{NON-DAIRY PRODUCTS}

Non-dairy products include non-dairy ice-cream, whipped topping, reconstituted filled milk, coffee creamer and cheese analogs. Vegetable oils are commonly used to replace milk fat in imitation dairy products. These products have better keeping properties than those containing milk fat, especially when palm oil is used. PO, PKO and their fractions are versatile materials with many applications in non-dairy products.

\section{Ice-cream}

Ice-cream is a complicated food colloid made up of fat globules $\left(1 \mathrm{~nm}^{-1} \mu \mathrm{m}\right.$ in size), air bubbles, ice crystals and an unfrozen serum phase (Goff, 1997). Production of ice-cream involves numerous steps of process which includes mixing preheating, homogenisation, pasteurisation, ageing, cooling, freezing and packaging. The ingredients in ice-cream play a major role in determining its quality although it is predominantly dependent on its processing and freezing conditions. Sensorial properties of ice-cream such as texture, resistant to melt and mouthfeel are dictated by ice-cream structure (Granger et al., 2005; Adapa et al., 2000). Fat has significant contribution to ice-cream properties (Goff, 1997) in which milk fat is the traditional fat for ice-cream. The fat content of $10 \%-16 \%$ is common in ice-cream in which different types of fat and amount affect the end product (Adapa et al., 2000). The requirements for ice-cream fat are that they should be partly solid at $-5^{\circ} \mathrm{C}$ to $+5^{\circ} \mathrm{C}$, substantially liquid at $37^{\circ} \mathrm{C}$ and good melt in the mouth characteristics (Berger, 1990).

PO and PKO are widely used commercially to replace butterfat in ice-cream formulation. Not only economical and easily available, the use of $\mathrm{PO}, \mathrm{PKO}$ and their fractions in ice-cream formulation, due to their physical characteristics, produces ice-cream of good texture, mouthfeel and stability especially upon storage. The sharp melting properties of PKO is found to be suitable for ice-cream. Fat blend consisting of $60 \%-100 \% \mathrm{PO}$ and $0 \%-40 \%$ PKO has been reported to be manufactured in commercial scale (Berger and Nor Aini, 2005). Further cost reduction in ice-cream production can be achieved when PO is mixed with 10\%-15\% POs. PMF (IV 4045) having high solid content at $5^{\circ} \mathrm{C}$ with low solid content at $35^{\circ} \mathrm{C}$ is also suitable fat for ice-cream as it melts completely below body temperature (Wan Rosnani et al., 2017).

The versatility of $\mathrm{PO}$ and $\mathrm{PKO}$ and their fractions in ice-cream production has been reported by many researchers. Ramli et al. (2008b) reported that apart from $\mathrm{POo}, \mathrm{PKO}$ and $\mathrm{PMF}$, red $\mathrm{POo}$ is also suitable for the production of ice-cream. Okiyama et al. (1993) used PO and skimmed milk blend in their ice-cream to study the applicability of bacterial cellulose in ice-cream. Nadeem et al. (2009) reported that incorporation of $3 \%$ POo with $1.5 \%$ milk fat shows no adverse effect on flavour, $\mathrm{pH}$ and melting quality of the ice-cream. In addition, Sung and Goff (2010) found that the use of PKO and high oleic SFO produces ice-cream of excellent structure and high melt resistance. Interesterified PKOo and anhydrous milk fat in 70\%:30\% ratio is also suitable to produce ice-cream of excellent melting characteristics (Liew et al., 2001).

\section{Cheese Analogs}

Cheese substitutes or cheese imitates, have long gained popularity among the food processors due to their cost-effectiveness in the production which normally use cheaper non-dairy fats or proteins to replace the costly milk-derived ingredients (Bachmann, 2001; Guirguis et al., 1985). Cheese substitutes are well-accepted among consumers as they can be manufactured to be nutritionally equivalent or have more nutritional benefits than the natural cheese. Cheese substitutes can be classified according to the manufacturing processes namely filled cheese and cheese analogs. Vegetable oils are often used in both types of cheese analogs 
to substitute the milk fat which is normally used in cheese making. Fats in cheese are crucial as they have great impact on flavour, mouthfeel, appearance and texture (Hill, 2017) as well as firmness, springiness and mouthfeel (Lucca and Tepper, 1994). Milk fats is a major ingredient in most cheese varieties. However, milk fat is mostly substituted due to its high cost and to lower the cholesterol level in cheese varieties (Aljewicz et al., 2011). Substituting milk fat with monounsaturated fatty acids and/ or polyunsaturated fatty acids has been proven to have a lowering effect on the serum cholesterol level in humans (Calleros et al., 2002). Studies on the development of cheese using hydrogenated vegetable oils including PKO, cottonseed, soyabean, coconut, corn or peanut oils have been reported by Lobato-Calleros and Vernon-Carter (1998), ArellanoGomez et al. (1996), Brander et al. (1985) and Shaw (1984).

Among all vegetable oils, PO is an excellent fat to substitute milk fat in the production of cheese analog without the need of hydrogenation and being free from cholesterol. Moreover, PO is rich in natural vitamin $\mathrm{E}$ which has an advantage of reducing the cholesterol concentration in serum as well as having an antioxidant effect (Noronha et al., 2007). Many studies have shown that palm-based fats can be used in the production of cheese analogs of excellent physical and organoleptic properties. Awatif et al. (2016) incorporated different levels of PO in Mozzarella cheese analogue to study the effect of PO levels and storage period on the characteristics and organoleptic properties of Mozzarella cheese and found that Mozzarella cheese containing 2\% PO had better organoleptic properties compared to those containing $0 \%, 1 \%, 3 \%$ and $4 \%$ of PO. Dinkçi et al. (2011) studied the effect of PO-based vegetable fat on Kashar-like cheese and found that cheese made from PO-based vegetable fat was acceptable for consumption based on the organoleptic and texture scores. Ismail et al. (2015) used PO in Feta cheese analog to study the effect of the properties of functional Feta cheese by partial substitution of milk fat and found that the product had excellent physical (colour, appearance, body and texture) and organoleptic (flavour) properties. Karimah (1996) showed that trans-free palm-based processed cheese could be made with a combination of $30 \% \mathrm{PO}$ and $70 \%$ PKOo. The advantages of using palm-based products included improved nutritional value, better functionality and quality preservation. Mozzarella analogs which exhibit smooth appearance, good shredability and meltability have been formulated using $\mathrm{PO}, \mathrm{PKO}$ and palm fractions. As well as savings in the manufacturing process, the raw materials are considerably cheaper than milk, with vegetable oil cheaper than butterfat and casein up to $50 \%$ cheaper than skim-milk powder (Karimah et al., 2001).

\section{Yogurt}

Yogurt is defined as coagulated milk products produced by culturing dairy ingredients such as cream, milk, partially skimmed milk, and skim milk by bacteria culture that produce the lactic acid (FAO/WHO Codex Alimentarius Commission). Yogurt was traditionally made from milk with no added ingredients. To improve yogurt texture, milk or skim milk was fortified with other materials such as non-fat dry milk, whey protein concentrate and some other dairy or plant-based ingredients. Yogurt contains not less than $3.25 \%$ milk fat and not less than $8.25 \%$ milk solids non-fat, and has a titratable acidity of not less than $0.9 \%$, expressed as lactic acid. Yogurt may be heat treated after fermenting to destroy viable microorganisms for a longer shelflife (Trachoo, 2002).

The milk fat in yogurt formulation could be replaced with vegetable fat such as $\mathrm{PO}$, coconut and soyabean oils. Palm-based yogurt with 5\% fat, formulated using a blend of $\mathrm{PO}$ and $\mathrm{PKO}$ received a high sensory score in terms of texture, colour, aroma, taste and overall acceptability. Palm-based yogurt has several advantages, e.g., it contains essential fatty acids and micronutrients such as vitamin E from palm blends, it is free of cholesterol and more economical (Nor Aini et al., 2002).

\section{Whipped Topping}

Whipped topping, an oil-in-water emulsion, is similar to other whippable emulsions such as whipping cream and ice-cream. Whipped topping is used for commercial and consumer use on puddings, sodas, cakes, ice-cream, fruits, pastries and cream pie bases. The fat component and its fatty acids greatly influence the whipping properties and stability of cream. Generally, the fat for whipping cream should be partly solid at $5^{\circ} \mathrm{C}$, solid enough at ambient temperature, and melt at $<37^{\circ} \mathrm{C}$ (body temperature) (Berger, 1988).

Being partly solid at $5^{\circ} \mathrm{C}$ and solid enough at ambient temperature, $\mathrm{PO}$ and PKO-based blends are suitable to be used in whipped topping formulation (Wan Rosnani et al., 2006). Towler (1982) reported that whipping creams made from $\mathrm{PO}$ and $\mathrm{PKO}$ were generally more stable than dairy whipping cream. Shamsi et al. (2002) found that PO and PKO-based whipping creams had excellent foam stability. Nesaretnam et al. (1993) reported that whipping cream made from an interesterified blend of $\mathrm{PO}$ and fully hydrogenated PKO in the ratio of 66\%:34\% was proven to have satisfactory whipping performance when compared to creams and is generally more stable than dairy creams. 


\section{CREAMER}

The function of a creamer is to develop a desirable colour change and impart body to the beverage or foods to which it is added. A properly formulated creamer would also impart a desirable cream-like flavour and taste. Non-dairy creamers are used as substitutes for dairy cream, or evaporated milk, in beverages such as coffee, tea and cocoa and in foods such as dessert and savoury dishes. They are developed to the point where they are virtually indistinguishable from natural (dairy) cream (Fazio, 1994). Non-dairy creamer is not considered as dairy product as it is lactose-free (Nguyen et al., 2016).

Non-dairy creamers normally contain about $20 \%-40 \%$ fat, $10 \%$ protein (either skim milk solids, more usually sodium caseinate) and 35\%-65\% carbohydrate (e.g., corn syrup solids) (Gardiner, 1977). Palm-based creamer can be formulated from $\mathrm{PO}, \mathrm{PKO}$ and their fractions. Either in powder or liquid form, palm-based creamer could replace dairy- or coconut-based creamer in various beverages and foods. It can substitute coconut milk or santan kelapa which is a very popular ingredient in South-east Asia, especially in the preparation of savory dishes like creamed rice or nasi lemak and curries. It is also used to replace coconut milk in the preparation of traditional Malaysian desserts like kuih lapis, kuih bingka, bubur, cendol and air batu campur (Noor Lida and Miskandar, 2017). A properly formulated palm-based creamer will also impart a desirable cream-milk flavour to be used as creamer for beverages. Formulations and process for the making of non-dairy creamer based on $\mathrm{PO}$ and $\mathrm{PKO}$ are described in patents filed by Cheng and Franz (2006) and Campbell and Morley (1992).

The advantages of palm-based creamer over dairy creamer are its economical price and nutritional properties. Dairy-based creamer contains cholesterol (Pordy, 1994) and trans fatty acids. Palm-based creamer is a healthful creamer and free of cholesterol and trans fatty acids. It can be formulated to contain high monounsaturated fatty acids, reduced saturated fatty acids or balanced monounsaturated, polyunsaturated and saturated (1:1:1) fatty acids. As it is formulated using palm-based oils, it contains an appreciable amount of vitamin E (Noor Lida and Miskandar, 2017).

\section{FILLED MILK}

Filled milk is available in three forms, i.e., sweetened condensed, evaporated and powdered (Nor Aini et al., 2002). Filled milk is basically meant to replace fresh milk and full cream milk products such as sweetened condensed milk, evaporated milk or full cream milk powder which are often expensive, contain trans fatty acids and cholesterols.
Furthermore, many people, especially in African and Asian countries, are intolerance to milk, and there are others who want to avoid animal fats (due to religious or health reasons). As a result, in many applications, it has been found attractive to replace the milk fat naturally present (at about 3.5\%) in the milk products with vegetable fat.

As milk is extremely susceptible to deterioration resulting in off flavours which can be easily detected by the consumers, the oxidative stability of the oil is a very important criterion in formulating a filled milk product. Only oils and fats with a bland taste and high stability can be used. Therefore, oils and fats with a low content of linoleic acid, no linolenic acid and a good level of natural antioxidant are preferred. The choice is usually made from $\mathrm{PO}$ and lauric fats (PKO and coconut oil). PO is cheaper and more stable to oxidation than butterfat, while lauric fats give a better mouthfeel. Therefore, 100\% PO, $100 \%$ POo and $100 \%$ fully hydrogenated PKO (IV max 2) can be used for filled milk (evaporated, sweetened condensed or powder) formulation (MPOB, 2017; Nor Aini et al., 2002).

\section{SANTAN SAWIT}

$\mathrm{PO}, \mathrm{PO}$ and $\mathrm{PKO}$ can be used in the preparation of coconut milk substitute called palm-based santan. The palm-based santan and coconut santan have similar proximate compositions as well as appearance, colour, aroma, and taste when prepared in savory cuisines and desserts (Zaida et al., 2008; 1997). Rafidah et al. (2013) found that nasi lemak made of palm-based santan was comparable to that of coconut milk in its sensory attributes, except for its colour, odour and overall taste. The main benefits of santan sawit are that it is cholesterol free, low fat (contains two times lower fat compared to coconut milk), nutritious (contains vitamins A and E), longer shelf-life (up to five months in package and 30 days after opening), saving of up to $50 \%$ (e.g., usage of $200 \mathrm{ml}$ santan sawit is equivalent to $400 \mathrm{ml}$ regular coconut milk ) and simply delicious (similar texture, taste and smell as regular coconut milk) (Tan, 2016; Zaida et al., 2016; 2013). Replacing the coconut milk with santan sawit in Malaysian dishes or snacks would be beneficial in reducing total serum cholesterol and hence, reducing cardiovascular risk (Ng and Tee, 1998).

\section{ANIMAL FAT REPLACER}

Animal fat is a major constituent in the production of processed meat such as nuggets, frankfurters and burgers as it provides texture and flavour to the end products. However, it has been described as the main factor for numerous diseases related to diet. 
This is mostly due to the contents of its saturated fatty acid, trans fatty acid as well as cholesterol (Rafidah et al., 2015; Ospina et al., 2012). Animal fat substitution with vegetable fat would be able to eliminate or reduce these parameters.

$\mathrm{PO}$ and its fraction POo dan POs have been reported as vegetable fats that are suitable to be used as animal fat replacer. The blend of PO and POs is suitable for partial substitution of chicken fat in chicken frankfurters in which it is comparable to commercial sample in terms of its sensory properties. The incorporation of POo in meat batter was found to eliminate fat and water separation problem. Chicken fat substitution with POo received greater acceptance by sensory panellists in which it was rated to have good hardness, oiliness, chicken flavour as well as overall acceptance (Tan et al., 2006; 2001). A study by Hsu and Yu (2002) shows that partial PO substitution is suitable for the making of low-fat emulsified meatball (Kung-wans). Vural and Javidipour (2002) found that interesterified PO was able to partially replace beef fat in frankfurters formulation. In addition, Rafidah et al. (2015) have successfully produced vitamin E-enriched palm fat vegetable nuggets. Nuggets formulated with $6.4 \%$ vitamin E-enriched palm fat was found the best for the formulation.

\section{MICROENCAPSULATED PALM-BASED PRODUCTS}

Microencapsulation is a method in which tiny particles or droplets of bioactive components are surrounded by a coating or wall material, to form small capsules or microcapsules (Calvo et al., 2011; Gharsallaoui et al., 2007). The wall material protects the bioactive core materials from chemical and physical reactions to maintain the biological, functional, and physico-chemical properties of the core materials. Microencapsulation is one of the techniques used for downstream processing of $\mathrm{PO}$ and processed PO products. Droplets of liquid oil or solid fat particles of PO-based products (core material) are coated with a thin film of the encapsulating agent (e.g., a polymer). The cover over the core material protects it against deterioration, then releases it under the desired conditions (Fang and Bhandari, 2010; Young et al., 1993; Dziezak, 1988).

There are numerous techniques for producing microencapsules. The choice, to a great extent, depends on the core material to be treated. The most common technique for oils and fats is spray drying which produces fine oils or fats powders. The process is economical and flexible, and only requires equipment that is readily available, and produces products of good quality (Reineccius, 1988; Heath and Reineccius, 1986). The coating material for spray drying should have a bland flavour, high solubility, and possesses the necessary emulsification, filmforming and good drying properties (Young et al., 1993; Balassa and Fanger, 1971). In addition, its concentrated solution should have low viscosity. The variety of coating materials commonly used include natural gums, carbohydrates and proteins (Dziezak, 1988).

The applications of PO-based products in food formulations can be extended by using microencapsulation technique. It has been shown that under carefully selected conditions and process, microencapsulated or powdered palmbased oil containing up to $70 \%$ PO (or higher with the higher melting fraction of $\mathrm{PO}$, e.g., POs), can be produced. The microencapsulated PO-based oils have good flowing properties and are mechanically stable (Noor Lida et al., 1996b). Microencapsulation technique has also been applied to protect and improve the functionality and properties of red PO/POo as reported by Voon et al. (2013) and Noor Lida et al. (1996b). Red PO is one of the richest sources of vitamin E (tocotrienols 70\%80\% and tocopherols 20\%-30\%) (Mukherjee and Mitra, 2009) and carotenoids of which $80 \%-90 \%$ is present as $\alpha$-carotene and $\beta$-carotene (Benadé, 2013). It also contains appreciable amounts of phospholipids, ubiquinones, sterols, and squalene (Choo et al., 2005) and phenolic compounds (Sambanthamurthi et al., 2011). The micronutrient in PO especially in the red PO has been found to have potent protective effects against chronic diseases, that is, cardiovascular disease, diabetes, and cancer (Che Idris et al., 2014; Benadé, 2013). Microencapsulated or powdered palm-based fats containing vitamin E, carotenoids and other palmbased micronutrients can be produced using spray drying technique. Voon et al. (2013) used spray drying technique to produce microencapsulated or powdered red POo with the aim to deliver the lipophilic nutrients of red POo in an encapsulated system for better organoleptic acceptability, sensory and nutritional values, shelf-life stability and ease of handling and storage. Once dried, the products can be packaged and stored at room temperature for long periods of time. The red POo in the dried form is able to reduce or eliminate the unpleasant colour, taste and odour of the red POo. It can be incorporated into a beverage product, food product, or other aqueous system suitable for consumption by a human or animal. Noor Lida et al. (1996b) used spray drying technique to produce microencapsulated palm-based fat containing vitamin $\mathrm{E}$ and carotene from red POo and POs in the ratio of $60 \%: 40 \%$. Omar et al. (2001) prepared an instant flavour ingredient by microencapsulation of POo with pandan, ginger, lemongrass and durian extract. The encapsulated powders have moisture, oil and surface oil content at 2.0-2.7, 56.8-68.1 and 15.2\%- 
$20.5 \%$, respectively, and gas chromatographic analysis revealed that more than $75 \%$ natural flavors were encapsulated in the dried powders. The microencapsulated PO-based oils can be used in many food applications, e.g., in dry food mixes, powdered functional foods or beverages, emulsions, tablets and nutraceutical products.

\section{MAYONNAISE AND SALAD DRESSINGS}

Mayonnaise, as defined by the US Food and Drug Administration (FDA), is a semi-solid emulsion type of food formulated with vegetable oil, acidifying ingredients and egg yolk. It may contain other optional ingredients such as salt, sweetener and spices (Depree and Savage, 2001). It is also referred to as concentrated oil-in-water emulsion type of food. To be qualified as a good mayonnaise product, the emulsion should not separate or break upon storage. The oil content in traditional mayonnaise is normally more than $65 \%$ and may go up until $80 \%$ to provide creamy texture as well as lubrication. Liquid oil with a good chill or cold stability at relatively low temperatures is preferred in the manufacture of mayonnaise and salad dressing (Wan Rosnani et al., 2015; Das et al., 2013; Ibrahim et al., 2007; Nor Aini, 1995).

The use of POo especially double-fractionated (IV60) POo as salad oil for mayonnaise and salad dressing can be made possible by blending with other vegetable oils such as soyabean and corn oil. Apart from consistent supply and competitive price compared to other liquid vegetable oils, the high content of vitamin E, a natural antioxidant, would give POo overwhelming advantage over other vegetable oil as vitamin $E$ would improve the oxidative stability of the products (Nor Aini, 1995). Nor Aini (1995) found that POo of IV > 60 is suitable for mayonnaise and salad dressings. POo with IV of $<58$ alone was not suitable for mayonnaise and salad dressings as the product would harden when refrigerated. Palma et al. (2004) incorporated PO in their low-fat mayonnaise formulation and found that it received high acceptability, comparable to mayonnaise formulation made of soyabean oil. Ibrahim et al. (2007) reported that mayonnaise-like emulsion could be produced by blending soyabean oil with PKOo. The emulsion had better storage stability when $10 \%-30 \%$ of PKOo were incorporated in the formulation. In a study by Das et al. (2013), a blend of rice bran oil and POs at a ratio of 65\%:35\% produced soft mayonnaise with perfect appearance while blending ratio of 70\%:30\% resulted in soft and creamy mayonnaise. Wan Rosnani et al. (2015) showed that mayonnaise which has good texture, $\mathrm{pH}$, particle size and refrigeration stability could be produced by blending POo with IV of $>58$ with SFO.

\section{INFANT FORMULA}

POo has been found to be very suitable for use in infant formulation when blended with other vegetable oils. POo contains $10 \%-15 \%$ palmitic acid in the sn-2 position of the TAG molecules. This contributes to the high digestibility of the products (Traitler and Diefenbacher, 1985). Palm-based oil also can be incorporated in infant milk formulation to mimic the fatty acid of human breast milk through $s n-1,3$ specific interesterification of high melting POs (which is high in PPP) with other oils and fats and essential fatty acids as described in Zou et al. (2012a, b; 2011). A palm-based fat composition particularly for use in a nutritionally complete infant formula is described in a patent by Tomarelli (1991). A study by Yu et al. (2009) to evaluate the effects of infant formula containing $\mathrm{PO}$ on the nutrient absorption in infants showed that the absorption of fat and calcium was higher when the infant formula provided with palmitic acid at the $s n-2$ positions as compared with using the infant formula without palmitic acid.

\section{PALM-BASED SPRAY COOKING OIL}

Palm-based spray cooking oil in a pressurised container offers a non-stick medium for frying. It is specially designed for the preparation of omelet, pancake, spaghetti, bread, macaroni, fried rice and instant fried noodle. It prevents foods from sticking, making it an excellent choice for baking or pan-frying. The spray cooking oil can be used for instant cooking, frying and roasting outdoors such as during camping, fishing and picnicking. It can also be sprayed on roasted/grilled meat and chicken or in salad dressings. The food calorific value can be controlled when cooking and frying with this spray cooking oil. The major ingredient in the palm-based spray cooking oil is POo. The spray POo has $45 \%$ monounsaturated and $12 \%$ polyunsaturated fatty acids. It also contains natural vitamin E. It has a natural odour, so it will not interfere with the taste of the food. An emulsifier is added to prevent the fried product from sticking to the frying pan during cooking. A food grade propellant is added to make the product spray easily (Omar et al., 2004).

\section{DIETARY SUPPLEMENT}

A dietary supplement is either intended to provide nutrients in order to increase the quantity of their consumption, or to provide non-nutrient chemicals which are claimed to have a biologically beneficial effect. Dietary supplements include such ingredients as vitamins, minerals, herbs, amino acids, and 
enzymes. Dietary supplements are marketed in the forms of tablets, capsules, soft gels, powders and liquids. The intended use of dietary supplements is to ensure that a person gets enough essential nutrients. Dietary supplements should not be used to treat any disease or as preventive healthcare (USFDA, 2017).

$\mathrm{PO}$ is rich in micronutrients such as carotenoids, tocopherols, tocotrienols, sterols, phospholipids, squalene, and tripterpenic and aliphatic hydrocarbons (Goh et al., 1985). The carotenoids, tocopherols, and tocotrienols are the most important minor components of PO. Together, they contribute to the stability and nutritional properties of $\mathrm{PO}$ (Ooi et al., 1996). Carotenoids impart the orangered colour to crude PO. Carotenoids, in particular $\alpha$ - and $\beta$-carotene, are precursors of vitamin $\mathrm{A}$ that are converted into vitamin $\mathrm{A}$ in vivo. In its crude form, PO is also high in carotenoids (500$\left.800 \mathrm{mg} \mathrm{kg}^{-1}\right)$, in the form of $\alpha$-carotene, $\beta$-carotene, $\gamma$-carotene, lycopene and xanthophylls (Choo and $\mathrm{Ng}, 2010)$. Rice and Burns (2010) and Zeba et al. (2006) suggested that PO carotenes improve vitamin A status in individuals with vitamin A deficiency. Nguyen et al. (2001) and Stuijvenberg et al. (2000) reported that South African and Vietnamese children who were fed with foods enriched with PO carotenes had significantly higher serum retinol. Carotenes have also been reported as having antioxidant and anti-cancer properties (Ashfaq et al., 2001). Tocopherols and tocotrienols are vitamin $\mathrm{E}$ isomers which are present in high amount (800-1270 $\mathrm{mg} \mathrm{kg}^{-1}$ ) in PO (Puah et al., 2007). Palm vitamin $\mathrm{E}$ possesses unique properties such as antioxidant (Cerecetto and López, 2007), cardioprotective (Heng et al., 2013), neuroprotective (Mangialasche et al., 2010), anti-cancer and cancer suppression (Wong and Radhakrishnan, 2012; Nesaretnam et al., 1998), nephroprotective (Siddiqui et al., 2010), anti-diabetic (Siddiqui et al., 2013), gastroprotective (Azlina et al., 2005), hepatoprotective (Ngah et al., 1991) and neurologic and brain development effects (Traber, 2014).

Palm-based dietary supplement such as vitamin $\mathrm{E}$ and carotenes have long been commercially available. Red PO/POo is suitable to be used in many dishes. One tablespoon of red POo a day provides enough carotenes and vitamin $\mathrm{E}$ for children requirements (Nor Aini et al., 2002). A study on the efficacy of utilising red $\mathrm{PO}$ as a source of carotene in rectifying vitamin A deficiency in school children in India conducted by Manorama et al. (1996) showed that red PO is an efficient source of $\beta$-carotene and can be used for supplementary feeding programmes to combat vitamin A deficiency in target population. In Guatemala, a similar recommendation was made to use red POo to combat vitamin A deficiency (International Vitamin A Consultative Group, 1996). Red PO/POo has also been used to combat vitamin
A deficiency in lactating mothers (Canfield et al., 2001). Thus, red PO/POo is highly efficacious in improving vitamin A status among populations at risk of vitamin A deficiency around the world (Sommerburg et al., 2015; Rice and Burns, 2010). A number of epidemiological studies have demonstrated an inverse correlation between dietary intake or blood level of vitamin A/ carotenoids and cancer risk, as well as an anticarcinogenic effect for these compounds. The inhibition of chemical carcinogenesis by $\mathrm{PO}$ carotenoids with reference to Benzo(a) pyrene metabolites in vivo and in vitro in rat hepatic cells has been reported by Tan and Chu (1991). The inhibitory effect palm carotenoids on the proliferation of a number of human cancer cells, which include the neuroblastoma, GOTO, pancreatic cancer PANC-1, glio-blastoma A172 and gastric cancer HGC- 27, has been reported by Murakoshi et al. (1989).

Apart from liquid red $\mathrm{PO} / \mathrm{POo}$, palm vitamin $\mathrm{E}$ and carotenes supplements are also available in emulsion, soft gel, capsule and tablet forms.

\section{OTHER FOOD USES}

PO, PKO and their fractions could also be used in sugar confectioneries, expanded and extruded snack, peanut butter, can soup and sardine, biscuit spray oil and others (MPOB, 2017).

\section{CONCLUSION}

$\mathrm{PO}$ and PKO and their fractions are very versatile. They can be used in a myriad of food applications from cooking/frying oil to margarine, vanaspati, shortenings, fat spreads, confectionery fat, icecream, cheese analogs, animal fat replacer, filled milk, mayonnaise and salad dressing, coconut milk analog, health supplements, and many others. The versatility of $\mathrm{PO}, \mathrm{PKO}$ and their fractions in food applications is attributable to their availability, competitive price (in the case of $\mathrm{PO}$ and its fractions), their distinctive quality such as their natural excellent oxidative stability (in the case of $\mathrm{PO}$ and POo), unique solid content profile, high nutritional value (free of trans fatty acids and cholesterols, and high in micronutrients), antioxidant properties and naturality (non-genetically modified organism, nonGMO).

\section{ACKNOWLEDGEMENT}

The authors thank the Director-General of MPOB for permission to publish this article. 


\section{REFERENCES}

ABDULKARIM, S M; LONG, K; LAI, O M; MUHAMMAD, S K S and GHAZALI, H M (2007). Frying quality and stability of high-oleic Moringa oleifera seed oil in comparison with other vegetable oils. Food Chemistry, 105: 1382-1389.

ABIGOR, R D; MARMER, W N; FOGLIA, T A; JONES, K C; DICICCIO, R J; ASHBY, R and UADIA, P O (2003). Production of cocoa butter-like fats by the lipase-catalyzed interesterification of palm oil and hydrogenated soybean oil. J. Amer. Oil Chem. Soc., 80: 1193-1196.

ADAPA, S; SCHMIDT, K. A; JEON, I J; HERALD, T J and FLORES, R A (2000). Mechanisms of ice crystallization and recrystallization in ice cream: a review. Food Reviews International, 16: 259-271.

ADHIKARI, P; SHIN, J A; LEE, J-H; HU, J N; ZHU, X M; AKOH, C C and LEE, K T (2010). Production of trans-free margarine stock by enzymatic interesterification of rice bran oil, palm stearin and coconut oil. J. Science of Food and Agriculture, 90: 703711.

ADHIKARI, P and HU, P (2012). Enzymatic and chemical interesterification of rice bran oil, sheaolein, and palm stearin and comparative study of their physicochemical properties. J. Food Science, 77: C1285-C1292.

AGUILAR, N; ALBANELL, E; MI NARRO, B; GUAMIS, B and CAPELLAS, M (2015). Effect of tiger nut-derived products in gluten-free batter and bread. Food Science and Technology International, 21: 323-331.

ALJEWICZ, M; GRAŻYNA, C and BIELECKA, M M (2011). Cheese-like products, analogs of processed and ripened cheeses. Zywnosc-Nauka, Technologia, Jakosc, 18: 16-25.

ARELLANO-GOMEZ, L A; LOBATO-CALLEROS, C; AGUIRRE-MANDUJANO, E and LOBATOCALLEROS, M O (1996). Effect of using different fats in the microstructure and texture characteristics of cheese analogs. Proc. of the 1996 IFT Annual Meeting. p. 9.

ASHFAQ, R;SHARMA, S;DULLEY, T;SABOORIAN, M H; SIDDIQUI, M T and WARNER, C (2001). Clinical relevance of benign endometrial cells in postmenopausal women. Diagnostic Cytopathology, 25: 235-238.

AUGUSTINE, M A; HENG, L K and NOR AINI, I (1988). Evaluation of potato crisps fried in market sample of palm olein, corn oil and soya oil. Pertanika, 11: 393-398.

AWATIF, H Y; KAMAL AWAD ABDEL-RAZIG, A A R and MUNA, I A (2016). Effect of different levels of palm oil on the compositional quality of Mozzarella cheese during storage. American J. Research Communication, 4: 97-112.

AZLINA, M F; NAFEEZA, M I and KHALID, B A (2005). A comparison between tocopherol and tocotrienol effects on gastric parameters in rats exposed to stress. Asia Pacific J. Clinical Nutrition, 14: 358-365.

BACHMANN, H P (2001). Cheese analogues: a review. International Dairy J., 11: 505-515.

BALASSA, L L and FANGER, G O (1971). Microencapsulation in the food industry. CRC Review in Food Technology, 2: 245.

BASIRON, Y (2007). Palm oil production through sustainable plantations. European J. Lipid Science and Technology, 109: 289-295.

BASIRON, Y (2015). An overview of Malaysian palm oil in global oils and fats scenario. Paper presented at the Palm Oil Trade Fair and Seminar. Cairo, Egypt.

BASOGLU, F N; WETHERILT, H; PALA, M; YILDIZ, M; BIRINGEN, C and UNAI, M (1996). Improved quality of cooking and frying oil by blending palm olein. Proc. of the World Conference on Oil Seed and Edible Oil Processing. p. 159-168.

BENADÉ, A J S (2013). Red palm oil carotenoids: potential role in disease prevention. Bioactive Food as Dietary Interventions for Cardiovascular Disease (Watson, R R and Preedy, V R eds.). Academic Press, San Diego, USA. p. 333-343.

BERGER, K G and NOR AINI, I (2005). Formulation of zero-trans acid shortenings and margarines and other food fats with products of the oil palm. J. Amer. Oil Chem. Soc., 82: 775-782.

BERGER, K G (1990). Ice cream. Food Emulsions. $2^{\text {nd }}$ Edition. Marcel Dekker Inc, New York, USA. p. $367-$ 444.

BERGER, K G (1988). The use of palm and palm kernel oil in ice cream and whipped cream products. Presented at the Palm Oil Development Conference. 11-15 October 1988, Kuala Lumpur, Malaysia.

BERGER, K G (1981). Food uses of palm oil. PORIM Occasional Paper No. 2. PORIM, Bangi. 
BOCKISCH, M (1997). Fats as Foods. Fats and Oils Handbook (Bockisch, M, ed.). AOCS Press, Champaign, USA. p. 718-801.

BOOTELLO, M A; HARTEL, R W; LEVIN, M; MARTINÉZ-BLANES, J; REAL, C; GARCES, R; MATÍNEZ-FORCE, E and SALAS, J J (2013). Studies of isothermal crystallisation kinetics of sunflower hard-stearin-based confectionery fats. Food Chemistry, 139: 184-195.

BOOTELLO, $\mathrm{M}$ A; HARTEL, $\mathrm{R}$ W; GARCES, R; MATÍNEZ-FORCE, E and SALAS, J J (2012). Evaluation of high oleic-high staric sunflower hard stearins for cocoa butter equivalent formulation. Food Chemistry, 134: 1409-1417.

BORHAN, R H; SAID, M and MAT SAHRI, M (2011). Enzymatic interesterification of palm products for producing low calorie cocoa butter substitutes. $J$. Applied Science, 11: 3750-3754.

BRACCO, U; DIEFFENBACHER, A and KOLAROVIC, L (1981). Frying performance of palm oil liquid fractions. J. Amer. Oil Chem. Soc., 58: 6-12.

BRANDER, R W; RAAP, T A and GESSLER, J F (1985). Soy milk containing cheese analog. US patent $4,556,569$.

CAIN, F W; HUGHES, A D and SLANGER, H (1995). Non-hydrogenated coating fats. US patent $5,439,700 \mathrm{~A}$

CALLEROS, C L; RAMIREZ-SANTIAGO, C and OSORIO-SANTIAGO, V J (2002). Microstructure and texture of manchego cheese- like products made with canola oil, lipophilic and hydrophilic emulsifiers. J. Texture Studies, 33: 165-182.

CALVO, P; CASTANO, A L; HERNANDEZ, M $\mathrm{T}$ and GONZALEZ-GOMEZ, D (2011). Effects of microcapsule constitution on the quality of microencapsulated walnut oil. European J. Lipid Science and Technology, 113: 1273-1280.

CAMPBELL, I J and MORLEY, W G (1992). Nondairy creams and process of making. US patent $5,135,768$

CANFIELD, L M; KAMINSKY, R G; TAREN, D L; SHAW, E and SANDER, J K (2001). Red palm oil in the maternal diet increases provitamin A carotenoids in breastmilk and serum of the mother-infant dyad. European J. Nutrition, 40: 30-38.

CERECETTO, $\mathrm{H}$ and LOPEZ, G V (2007). Antioxidants derived from vitamin E: an overview. Mini Reviews in Medicinal Chemistry, 7: 315-338.
CHARTERIS, W and KEOGH, K (1991). Fats and oils in table spreads. Lipid Technology, 3: 16-22.

CHAVARRO, J E; STAMPFER, M J; CAMPOS, H; KURTH, T; WILLETT, W C and MA, J (2008). A prospective study of trans fatty acid levels blood and risk of prostate cancer. Cancer Epidemiol Biomaker and Preventive, 17: 95-101.

CHAVARRO, J E; RICH-EDWARDS J W; ROSNER, B A and WILLET, W C (2007). Dietary fatty acid intakes and the risk of ovulatory infertility. American J. Clinical Nutrition, 85: 231-237.

CHE IDRIS, C A; KARUPAIAH, T; SUNDRAM, K; TAN, YA; BALASUNDRAM, N; LEOW, S S; NASRUDDIN, $\mathrm{N} S$ and SAMBANTHAMURTHI, $R$ (2014). Oil palm phenolics and vitamin E reduce atherosclerosis in rabbits. J. Functional Foods, 7: 541750 .

CHEN, W A; CHIU, C P; CHENG, W C; HSU, C K and KUO, M I (2013). Total polar compounds and acid values of repeatedly used frying oils measured by standard and rapid methods. J. Food and Drug Analysis, 21: 85-85.

CHENG, T and FRANZ, S (2006). Aseptic liquid non dairy creamer. Patent application No. US 11/546,070. https:/ / www.google.com/patents / US20070092628, accessed on 12 September 2017.

CHIN, N L; ABDUL RAHMAN, R; MAT HASHIM, D and KOWNG, S Y (2010). Palm oil shortening effects on baking performance of white bread. J. Food Process Engineering, 33: 413-433.

CHOO, Y M (2013). Palm oil: a versatile ingredients for food and non-food applications. Presented at the Malaysia-Vietnam Palm Oil Trade Fair and Seminar (POTS) 2013.

CHOO, Y M and NG, M H (2010). Phytonutrients from palm oil. Further Advances in Oil Palm Research. (Wahid, M B; Choo, Y M and Chan, K W eds.). MPOB, Bangi.

CHOO, Y M; NG, M H; MA, A N; CHUAH, C H and HASHIM, M A (2005). Application of supercritical fluid chromatography in the quantitative analysis of minor components (carotenes, vitamin E, sterols, and squalene) from palm oil. Lipids, 40: 429-32.

CHOO, Y M; MA, A N; CHUAH, C H; KHOR, H $\mathrm{T}$ and BONG, S C (2004). A development study on the appearance of tocopherols and tocotrienols in developing palm mesocarp (Elaeis guineensis), Lipids, 39: 561-564. 
CHOO, Y M; MA, A N and YAP, S C (1997). Carotenes, vitamin $\mathrm{E}$ and sterols in oils from Elaeis guineensis, Elaeis oleifera and their hybrids. Palm Oil Developments No. 27: 1-9.

CHU, B S; GHAZALI, H M; LAI, O M; CHE MAN, Y B and YUSOF, S (2002). Physical and chemical properties of a lipase-transesterified palm stearin/ palm kernel olein blend and its isopropanol-solid and high melting triacylglycerol fractions. Food Chemistry, 76: 155-164.

DAS, J; BHATTACHARYA, T; KAR, S; GHOSH, M and BHATTACHARYYA, D K (2013). Preparation of some nutritionally superior quality mayonnaise products. International J. Applied Sciences $\mathcal{E}$ Engineering, 1: 15-20.

DE CLERCQ, N; DANTHINE, S; NGUYEN, M; GIBON, V and DEWETTINCK, K (2012). Enzymatic interesterification of palm oil and fractions: monitoring the degree of interesterification using different methods. J. Amer. Oil Chem. Soc., 89: 219229.

DE MARCO, E; SAVARESE, M; PARISINI, C; BATTIMO, I; FALCO, S and SACCHI, R (2007). Frying performance of a sunflower/palm oil blend in comparison with pure palm oil. European J. Lipid Science and Technology, 109: 237-246.

DEMIRKESEN, I; SUMNU, G and SAHIN, S (2013). Quality of gluten-free bread formulations baked in different ovens. Food and Bioprocess Technology, 6: 746-753.

DEPREE, J A and SAVAGE, G P (2001). Physical and flavour stability of mayonnaise. Trends in Food Science E Technology, 12: 157-163.

DINKÇI, N; KESENKAS, H; SEÇKIN, A K; KINIK, Ö and GÖNÇ, S (2011). Influence of a vegetable fat blend on the texture, microstructure and sensory properties of kashar cheese. Grasas Y Aceites, 62: 275283.

DUNS, M L (1985). Palm oil in margarines and shortenings. J. Amer. Oil Chem. Soc., 62: 408-410.

DZIEZAK, J D (1988). Microencapsulation and encapsulated ingredients. Food Technology, 42: 136.

EDEM, D O (2002). Palm oil: biochemical, physiological, nutritional, hematological and toxicological aspects: a review. Plant Foods for Human Nutrition (Formerly Oualitas Plantarum), 57: 319-341.

EL-HADAD, N N M; YOUSSEF, M; ABD EL-AAL, M $\mathrm{H}$ and ABOU-GHARBIA, H H (2011). Utilisation of red palm olein in formulating functional chocolate spread. Food Chemistry, 124: 285-290.

EL-KALYOUBI,M;KHALLAF,MF;ABDELRASHID, A and EMAN, M M (2011). Quality characteristic of chocolate-containing some fat replacer. Annals of Agricultural Science, 56: 89-96.

FANG, Z and BHANDARI, B (2010). Encapsulation of polyphenols - a review. Trends in Food Science $\mathcal{E}$ Technology, 21: 510-23.

FAUR, L (1975). Palm oil in deep frying- comparative performances. Revue Francaise des Corps Gras, 22: 77-83.

FAZIO, S C (1994). Powdered dairy creamer. US patent 5,284,674.

FIRESTONE, D (2007). Regulation of frying fat and oil. Deep Frying: Chemistry, Nutrition, and Practical Applications. $2^{\text {nd }}$ ed. AOCS Press. p. 373-385.

FOGLIA, T A; PETRUSO, $\mathrm{K}$ and FEAIRHELLER, S H (1993). Enzymatic interesterification of tallowsunflower oil mixtures. J. Amer. Oil Chem. Soc., 70: 281-285.

FOMUSO, L B and AKOH, C C (2001). Enzymatic modification of high-laurate canola to produce margarine fat. J. Agricultural and Food Chemistry, 49: 4482-4487.

FRITCH, C W (1981). Measurements of frying fat deterioration: a brief review. J. Amer. Oil Chem. Soc., 58: 272-274.

GARDINER, D S (1977). Non-dairy creamer compositions. US patent 4,046,926.

GARIMA, P and AKOH, C (2013). Enzymatic modification of lipids for trans-free oil. J. Amer. Oil Chem. Soc., 6: 1138-1143.

GHARSALLAOUI, A; ROUDAUT, G; CHAMBIN, O; VOILLEY, A and SAUREL, R (2007). Applications of spray-drying in microencapsulation of food ingredients: an overview. Food Research International, 40: 1107-21.

GHOSH, S and BHATTACHARYYA, D K (1997). Utilization of high-melting palm stearin in lipasecatalyzed interesterification with liquid oils. J. Amer. Oil Chem. Soc., 74: 589-592.

GHOTRA, B S; DYAL, S D and NARINE, S N (2002). Lipid shortenings: a review. Food Research International, 35: 1015-1048. 
GOFF, H D (1997). Colloidal aspects of ice-cream - a review. International Dairy J., 7: 363-373.

GOH, S H; CHOO, Y M and ONG, A S H (1985). Minor constituents of palm oil. J. Amer. Oil Chem. Soc., 62: 237-40.

GOSLINE, A (2006). Why fast foods are bad, even in moderation. New Scientist, 6: 12.

GUIRGUIS, AH; ABDELBAKY, AA; EL-NESHAWY, A A and EL-SHAFY, N M (1985). Peanut curd in the manufacture of processed cheeselike spread. Dairy Industries International, 50: 37-41.

GRANGER, C; LEGER, A; BAREY, P; LANGENDORFF, $\mathrm{V}$ and CANSELL, M (2005). Influence of formulation on the structural networks in ice cream. International Dairy J., 15: 255-262.

HASHIMOTO, T; KATO, A; TANABE, K; MAMURO, H; YAMAOKA, M; BERGER, K G and ABD GAPOR, M T (1980). Studies on tocopherols and tocotrienols in Malaysian palm oil. Proc of the Intl. Symp. on the Advanced Industrial Utilization of the Tropical Plants. 1-4 September, Tsukuba, Japan.

HEATH, H B, and REINECCIUS, G (1986). Offflavors in foods. Flavor Chemistry and Technology. Macmillan Education, United Kingdom. p. 112-141.

HENG, E C; KARSANI, S A; ABDUL RAHMAN, M; ABDUL HAMID, N A; HAMID, Z and WAN NGAH, W Z (2013). Supplementation with tocotrienol-rich fraction alters the plasma levels of Apolipoprotein A-I precursor, Apolipoprotein E precursor, and C-reactive protein precursor from young and old individuals. European J. Nutrition, 52: 1811-1820.

HILL, A R (2017). Importance of fat in cheese. https: / / www.uoguelph. ca/foodscience/bookpage/importance-fat-cheese, accessed in August 2017.

HIMAWAN, C; STAROV, V M and STAPLEY, A G F (2006). Thermodynamic and kinetic aspects of fat crystallisation. Advances in Colloid and Interface Science, 122: 3-33.

HISHAMUDDIN, E, STAPLEY, A G and NAGY, Z K (2011). Application of laser backscattering for monitoring of palm oil crystallisation from melt. J. Crystal Growth, 335: 172-180.

HSU, S Y and YU, S H (2002). Comparisons on 11 plant oil fat substitutes for low-fat kung-wans. J. Food Engineering, 52: 215-220.

HU, P; XU, X and YU, L L (2017). Interesterified trans-free fats rich in $\mathrm{sn}-2$ nervonic acid prepared using Acer truncatum oil, palm stearin and palm kernel oil, and their physicochemical properties. LWT - Food Science and Technology, 76: 156-163.

HU, F B; VAN DAM, R M and LIU, S (2001). Diet and risk of type II diabetes: the role of types of fat and carbohydrate. Diabetologia, 44: 805-817.

IBRAHIM, N H; CHE MAN, Y; TAN, C P and IDRIS, N A (2007). Stability and rheology of concentrated $\mathrm{o} / \mathrm{w}$ emulsions based on soybean oil/palm kernel olein blends. Food Research International, 40: 10511061.

INTERNATIONAL VITAMIN A CONSULTATIVE GROUP XVII MEETING (1996). Guatemala. Nutrition Review, 3: 6.

ISMAIL, M M; EL-TAHRA, M A A; EL-SHAZLY A. K and EID, M Z (2015). The impact of partial replacement of milk protein concentrates by acid whey proteins and adding Bifidobacteria on some properties of functional analogue Feta cheese. American J. Food Science and Nutrition Research, 2: 10-20.

JEUNG, H L; AKOH, C C; HIMMELSBACH, D S and LEE, K T (2008). Preparation of interesterified plastic fats from fats and oils free of trans fatty acid. J. Agricultural and Food Chemistry, 56: 4039-4046.

JEYARANI, T; BANERJEE, T; RAVI, R and GOPALA, K A G (2015). Omega-3 fatty acids enriched chocolate spreads using soybean and coconut oils. J. Food Science and Technology, 5: 1082-1088.

JOHANSSON, D; BERGENSTÁHL, B and LUNDGREN, E (1995). Water-in-triglyceride oil emulsion. effect of fat crystals on stability. J. Amer. Oil Chem. Soc., 72: 8939-8950.

KAMYSHNY, A and MAGDASSI, S (2006). Microencapsulation. Encyclopedia of Surface and Colloid Science. DOI:10.1081/E-ESCS-120023308.

KARIMAH, A; YAZID, $\mathrm{M}$ and YUSOFF, M S A (1996). Production of palm-based processed cheese. PORIM Information Series No. 52, PORIM, Bangi.

KARIMAH, A; AMINAH, A and MOHD KHAN, A (2001). Potential of palm blend in the formulation of Mozzarella analogue. Palm Oil Developments No. 35: 1-7.

KELLENS, M; GIBON, V; HENDRIX, $M$ and DE GREYT, W (2007). Palm oil fractionation. European J. Lipid Science and Technology, 109: 336-349.

KHEIRI, M S A (1985). Palm oil products in cooking fats. J. Amer. Oil Chem. Soc., 62: 410-416. 
LAI, O M; GHAZALI, H M; CHO, F and CHONG, C L (2000). Physical and textural properties of an experimental table margarine prepared from lipasecatalysed transesterified palm stearin: palm kernel olein mixture during storage. Food Chemistry, 71: 173-179.

LAI, O M; GHAZALI, H M and CHONG, C L (1999). Use of enzymatic transesterified palm stearinsunflower oil blends in the preparation of table margarine formulation. Food Chemistry, 64: 83-88.

LAI, O M; GHAZALI, H M and LET, C C (1998a). Effect of enzymatic transesterification on the fluidity of palm stearin-palm kernel olein mixtures. Food Chemistry, 63: 155-159.

LAI, O M; GHAZALI, H and CHONG, C (1998b). Effect of enzymatic transesterification on the melting points of palm stearin-sunflower oil mixtures. J. Amer. Oil Chem. Soc., 75: 881-886.

LEE, Y Y, TANG, T K, PHUAH, E T, AB KARIM, N A, ALWI, S M M and LAI, O M (2015). Palmbased medium-and-long-chain triacylglycerol (P-MLCT): Production via enzymatic interesterification and optimization using response surface methodology (RSM). J. Food Science and Technology, 52: 685-696.

LEE, Y Y, TANG, T K and LAI, O M (2012). Health benefits, enzymatic production, and application of medium- and long-chain triacylglycerol (MLCT) in food industries: a review. J. Food Science, 77: R137-R144.

LEE, C H (2009). The optimum maintain of frying oil quality and the rapid measurements of acid value and total polar compounds. Taiwan Food News, 234: 70-78.

LEONARDIS, A D and MACCIOLA, V (2012). Heatoxidation stability of palm oil blended with extra virgin olive oil. J. Food Chemistry, 135: 1769-1776.

LIEW, M Y B; GHAZALI, H M; LONG, K; LAI, O $M$ and YAZID, A M (2001). Physical properties of palm kernel olein-anhydrous milk fat mixtures transesterified using mycelium-bound lipase from Rhizomucor meihei. Food Chemistry, 72: 447-454.

LIST, G R; EMKEN, E A; KWOLEK, W F; SIMPSON, T D and DUTTON, H J (1977). Zero-trans margarines: Preparation, structure, and properties of interesterified soybean oil-soy trisaturate blends. J. Amer. Oil Chem. Soc., 54: 408-413.

LIU, Y; MENG, Z; ZHANG, F; SHAN, L and WANG, X (2010). Influence of lipid composition, crystallization behavior and microstructure on hardness of palm oil-based margarines. European Food Research Technology, 230: 759-767.

LOBATO-CALLEROS, C and VERNON-CARTER, E J (1998). Microstructure and texture of cheese analogs containing different types of fat. J. Texture Studies, 29: 569-586.

LUCCA, P A and TEPPER, B J (1994). Fat replacers and the functionality of fat in foods. Trends in Food Science \& Technology, 5: 12-19.

MAHMOUD, M M; RADY, A H; FARIED A and EL-EGIEUL, A (1996). Blending of palm olein with cottonseed oil. Proc. of the 1996 PORIM International Palm Oil Congress - Chemistry \& Technology Conference. PORIM, Bangi. p. 286-300.

MPOB (2017). Pocketbook of Palm Oil Uses. $7^{\text {th }}$ Edition MPOB, Bangi.

MANGIALASCHE, F; KIVIPELTO, M; MECOCCI, P; RIZZUTO, D; PALMER, K; WINBLAD, B and FRATIGLIONI, L (2010). High plasma levels of vitamin $\mathrm{E}$ forms and reduced Alzheimer's disease risk in advanced age. J. Alzheimers, 20: 1029-1037.

MANORAMA, R; BRAHMAM, G N V and RUKMINI, C (1996). Red palm oil as a source of $\beta$-carotene for combating vitamin A deficiency. Plant Foods for Human Nutrition (Formerly Qualitas Plantarum), 49: 75-82.

MATTHÄUS, B (2007). Use of palm oil for frying in comparison with other high-stability oils. European J. Lipid Science and Technology, 109: 400-409.

MAYAMOL, P N; SAMUEL, T; BALACHANDRAN, A; SUNDARESAN, $C$ and ARUMUGHAN, C (2004). Zero trans shortening using palm stearin and rice bran oil. J. Amer. Oil Chem. Soc., 81: 407-413.

METIN, S and HARTEL, R W (1998). Thermal analysis of isothermal crystallisation kinetics in blends of cocoa butter with milk fat or milk fat fractions. J. Amer. Oil Chem. Soc., 75: 1617-1624.

MIÑARRO, B; ALBANELL, E; AGUILAR, N; GUAMIS, B and CAPELLAS, M (2012). Effect of legume flours on baking characteristics of glutenfree bread. J. Cereal Science, 56: 476-481.

MISKANDAR, M S; CHE MAN, Y B; YUSOFF, M S A and ABDUL RAHMAN, R (2004). Palm oil crystallization: Effect of cooling and palm oil content, J. Food Lipids, 11: 190-207.

MISKANDAR, M S CHE MAN, YB YUSOFF, M $S$ A and ABDUL RAHMAN, R (2006). Effect of 
emulsifiers on crystallization properties of lowmelting blends of palm oil and olein, J. Food Lipids, 13: $57-72$.

MISKANDAR, M S; CHE MAN, Y; YUSOFF, M S A and ABD RAHMAN, R (2005). Quality of margarine: fats selection and processing parameters. Asia Pacific J. Clinical Nutrition, 14: 387-395.

MISKANDAR, M S and NOR AINI, I (2010). Palm stearin as low trans hard stock for margarine. Sains Malaysiana, 39: 821-827.

MISKANDAR, M S and ZALIHA, O (2014). Minimising post-hardening in palm oil/sunflower oil soft margarine formulation by optimising processing conditions. J. Oil Palm Res. Vol. 26: 340353.

MUKHERJEE, S and MITRA, A (2009). Health effects of palm oil. J. Human Ecology, 26: 197-203.

MURAKOSHI, M; TAKAYASHU, J; KIMURA, O; KOHMURA, E and NISHINO, H (1989). Inhibitory effects of a-carotene on proliferation of the human neuroblastoma cell line GOTO. J. National Cancer Institute, 81: 1649-1652.

NADEEM, $\mathrm{M}$; ABDULLAH, $\mathrm{M}$; AYESHA and ELLAHI, M Y (2009). Effect of milk fat replacement with palm olein on physiochemical and sensory characteristics of ice cream. Pakistan J. Science, 61: 210-214

NAELI, M H; FARMANI, J and ZARGARAAN, A (2017). Rheological and physicochemical modification of trans-free blends of palm stearin and soybean oil by chemical interesterification. J. Food Process Engineering, 40: e12409.

NALLUSAMY, S (2006). The role of palm oil in the snack food industry. Paper presented at the International Palm Oil Trade Fair and Seminar. 2124 November 2006, Kuala Lumpur, Malaysia.

NESARETNAM K; STEPHEN R; RAY DILS R and PHILIPPA DARBRE P (1998). Tocotrienols inhibit the growth of human breast cancer cells irrespective of estrogen receptor status. Lipids, 33(5): 461-469.

NESARETNAM, K; ROBERTSON, N; BASIRON, $Y$ and MACPHIE, C S (1993). Application of hydrogenated palm kernel oil and palm stearin in whipping cream. J. Science of Food and Agriculture, 61: 401-407.

NG, T and TEE, E S (1998). Replacing coconut santan with palm oil santan: impact on dietary C12-16 saturated fatty acids, serum total cholesterol and cardiovascular risk. Malaysian J. Nutrition, 4: 65-72.
NGAH, W Z; JARIEN, Z; SAN, M M; MARZUKI, A; TOP, G M; SHAMAAN, N A and KADIR, K A (1991). Effect of tocotrienols on hepatocarcinogenesis induced by 2-acetylaminofluorene in rats. American J. Clinical Nutrition, 53: 1076S-1081S.

NGUYEN, T L (2001). Effect of red palm oil supplementation on vitamin $\mathrm{A}$ and iron status of rural underfive children in Vietnam. Proc. of the International Palm Oil Congress. 20-23 August 2001, Kuala Lumpur, Malaysia.

NGUYEN, $\mathrm{T}$ T; NGUYEN, $\mathrm{H}$ M; JARUNRATTANASRI, A and SINGANUSONG, $\mathrm{R}$ (2016). Production and quality of sterilized liquid non-dairy creamer from refined rice bran oil. Proc. of the $18^{\text {th }}$ Food Innovation Asia Conference 2016 (FIAC 2016). 16-18 June 2016, Bangkok, Thailand.

NOOR LIDA, H M D and MISKANDAR, M S (2017). Palm-based multipurpose liquid creamer. $M P O B$ Information Series No. 764. MPOB, Bangi.

NOOR LIDA, H M D; SIVARUBY, K; MISKANDAR, M S; ZALIHA, O and RAFIDAH, A H (2016a). Palm mid fraction-based hardstocks for cake margarines. MPOB Information Series No. 734. MPOB, Bangi.

NOOR LIDA, H M D; SIVARUBY, $\mathrm{K}$ and MISKANDAR, M S (2016b). Designed palm fat from palm fat high in symmetrical triglycerides for application in food and especially solid fat formulations. Patent application No. PI 2016001010.

NOOR LIDA, H M D; SIVARUBY, K; MISKANDAR, M S; ZALIHA, O and RAFIDAH, A H (2016c). Palm mid fraction-based hardstocks for cold spreadable table margarines. $\mathrm{MPOB}$ Information Series No. 735. $\mathrm{MPOB}$, Bangi.

NOOR LIDA, H M D; SUNDRAM, K and NOR AINI, I (2007). Effect of chemical interesterification on triacylglycerol and solid fat contents of palm stearin, sunflower oil and palm kernel olein blends. European J. Lipid Science Technology, 109: 147-156.

NOOR LIDA, H M D and MD ALI, A R (1998). Physico-chemical characteristics of palm-based oil blends for the production of reduced fat spreads. J. Amer. Oil Chem. Soc., 75: 1625-1631.

NOORLIDA, HMD; MD ALI, AR and MUHADHIR, I (1996a). Blending of palm oil, palm stearin and palm kernel oil in the preparation of table and pastry margarine. International J. Food Science and Nutrition, 47: 71-74.

NOOR LIDA, H M D; NOR'AINI, S and MOHD SURIA AFFANDI, Y (1996b). Characteristics of 
microencapsulated palm-based oil as affected by type of wall material. J. Science of Food and Agriculture, 70: $422-426$

NOR AINI, I and MISKANDAR, M S (2007a). Utilization of palm oil and palm oil products in shortenings and margarine. European J. Lipid Science and Technology, 109: 422-432.

NOR AINI, I and MISKANDAR, M S (2007b). Bakery fats from palm and soybean oils for short crust pastry. Proc. of the PIPOC 2007 International Palm Oil Congress - Product Development and Nutrition Conference. MPOB, Bangi. p. 61-62.

NOR AINI, I and NOOR LIDA, H M D (2005). Interesterified palm products as alternatives to hydrogenation. Asia Pacific J. Clinical Nutrition, 14: 396-401.

NOR AINI, I; RAZALI, I; OSMAIL, A and WAN ROSNANI, A I (2002). Palm oil: traditional, recent and potential applications in foods. Sains Malaysiana, 31: 241-259.

NOR AINI, I; MAIMON, C C; HANIRAH, H; ZAWIAH, S and MAN, Y C (1999). Trans-free vanaspati containing ternary blends of palm oilpalm stearin-palm olein and palm oil-palm stearinpalm kernel olein. J. Amer. Oil Chem. Soc., 76: 643648.

NOR AINI, I; LINA, L; SURIA, M A S and ARIF, S M (1997). Palm oil based trans free vanaspati. PORIM Information Series. PORIM, Bangi.

NOR AINI, I (1995). Use of palm olein in salad dressings. PORIM Information Series No. 26. PORIM, Bangi.

NOR AINI, I: HANIRAH, H; FLINGOH, C H O and NORAINI, S (1992). Resistance to crystallization of blends of palm olein with soybean oil stored at various temperatures. J. Amer. Oil Chem. Soc., 69: 1206-1209.

NOR AINI, I, BERGER, K G and ONG, A S (1989). Evaluation of shortenings based on various palm oil products. J. Science of Food and Agriculture, 46: 481493.

NORAZURA AILA, $\mathrm{M}$ H and NOOR LIDA, H M D (2017). Usage of palm oil, palm kernel oil and their fractions as confectionery fats. J. Oil Palm Res. Vol. 29: 301-310.

NORIZZAH, A R; CHONG, C L; CHEOW, C $S$ and ZALIHA, O (2004). Effects of chemical interesterification on physiochemical properties of palm stearin and palm kernel olein blends. Food Chemistry, 86: 229-235.

NORONHA, N; DOLORES O'RIORDAN, E and O'SULLIVAN, M (2007). Replacement of fat with functional fibre in imitation cheese. International Dairy J., 17: 1073-1082.

O'BRIEN, R D (2009). Fats and Oils: Fats and Oils: Formulating and Processing for Applications (O'Brien, R D ed.). CRC Press, Florida, USA.

O'BRIEN, R D (2008). Fats and oils processing. Fats and Oils: Formulating and Processing for Applications (O'Brien, R D ed.). CRC Press, Florida, USA, p. 57174.

O'BRIEN, R D and WAKELYN, PJ (2005). Cottonseed oil: an oil for trans-free option. Food Technology, 16: 677-679.

O'BRIEN, R D (2004). Shortening types and baking shortening. Fats and Oils: Formulating and Processing for Applications (O'Brien, R D ed.). CRC Press, Florida, USA, p. 291-337.

OKIYAMA, A; MOTOKI, $\mathrm{M}$ and YAMANAKA, S (1993). Bacterial cellulose IV. Application to processed foods. Food Hydrocolloids, 6: 503-511.

OLIVEIRA, GM; RIBEIRO, APB and KIECKBUSCH, $T$ G (2015). Hard fats improve technological properties of palm oil for applications in fat-based products. LWT - Food Science and Technology, 63: 11551162.

OMAR, M N; NOR-HAZWANI, M H; NAZREEN, M N and ZUBERDI, A M (2014). Studies on frying quality of virgin coconut oil and shortening blends. Oriental J. Chemistry, 30: 1279-1286.

OMAR, M N; MISKANDAR, M S and NOR AINI, I (2007). Palm-based solid fat for frying. $M P O B$ Information Series No. 387. MPOB, Bangi.

OMAR, M N; MOHD SURIA AFFANDI, $\mathrm{Y}$ and BURHANUDDIN, S (2004). Palm-based spray oil. MPOB Information Series No. 255. MPOB, Bangi.

OMAR, M N; IBRAHIM, N S; ANVARALI, M N and DESA, Z M (2001). Spray drying of natural flavours using palm oil. Paper presented at the Seminar on Medicinal and Aromatic Plants. Forest Research Institute Malaysia (FRIM). Kuala Lumpur, Malaysia.

OMONOV, T S; BOUZIDI, L and NARINE, S S (2010). Quantification of oil binding capacity of structuring fats: a novel method and its application. Chemistry and Physics of Lipids, 163: 728-740. 
OOI, C K; CHOO, Y M, YAP, C M and MA, A N (1996). Refining of red palm oil. Elaeis, 8: 20-28.

OSPINA-E, J C; SIERRA-C, A; OCHOA, O; PÉREZÁLVAREZ and FERNÁNDEZ-LÓPEZ (2012). Substitution of saturated fat in processed meat products: a review. Food Science and Nutrition, 52: 113-122.

PALMA, A; AZIZ, M G, CHAWDURY, M M; UDDIN, M B and ALAM, M (2004). Effect of edible oils on quality and shelf life of low fat mayonnaise. Pakistan J. Nutrition, 3: 340-343.

PANDE, G and AKOH, C (2013). Enzymatic modification of lipids for trans-free margarine. Lipid Technology, 25: 31-33.

PARVEEN, C (2000). Size distribution and morphology of fat crystals: inter-relationship with polymorphic form and texture. J. Texture Studies, 18: 303-318.

PEASE, J J (1985). Confectionery fats from palm oil and lauric oil. J. Amer. Oil Chem. Soc., 62: 426-430.

PÉREZ-ALONSO, C; CRUZ-OLIVARES, J; BARRERA-PICHARDO, J F; RODRÍGUEZ-HUEZO, M E; BÁEZ-GONZÁLEZ, J G and VERNONCARTE, E J (2008). DSC thermo-oxidative stability of red chili oleoresin microencapsulated in blended biopolymers matrices. J. Food Engineering, 85: 613624.

PERNETTI, M; VAN MALSSEN, K F; KALNIN, D and FLOTER, E (2007). Structuring edible oil with lecithin and sorbitan tri-stearate. Food Hydrocolloids, 21: $855-861$

PORDY, W T (1994). Low fat, low cholesterol, and low calorie dairy creamer. US patent 5,366,751.

PUAH, C W; CHOO, Y M; MA, A N and CHUAH, C H (2007). The effect of physical refining on palm vitamin E (tocopherol, tocotrienol and tocomonoenol). American J. Applied Sciences, 4: 374377.

RAFIDAH, A H; MOHD BURDA, F A; NOOR LIDA, H M D; SHAMSUDIN; S Y; AWG ISA, W R; AHMAD, KARIMAH; KANAGARATNAM, $S$ and MAT SAHRI, M (2015). Optimization of vitamin E-enriched palm fat, oat and xanthan gum in a gluten-based nugget formulation. J. Oil Palm Res. Vol. 27: 168-180.

RAFIDAH, A H; AZAHARI, N I A and SAHRI, M M (2013). A comparative study of the effects of processing conditions and formulations on the physical and sensory properties of frozen nasi lemak made of palm-based santan and coconut santan. J. Oil Palm Res.Vol. 25: 170-179.

RAMLI, M R; SIEW, W L; CHEAH, K Y; IDRIS, N A and MAT SAHRI, M (2008a). Physico-chemical properties and performance of high oleic and palmbased shortening. J. Oleo Science, 57: 605-612.

RAMLI, N;SYALIZA, AS and AWG ISA, W R(2008b). The effect of vegetable fat on the physicochemical characteristics of dates ice cream. International J. Dairy Technology, 61: 265-269.

RAZALI, I (2005). Palm oil and palm olein frying applications. Asia Pacific J. Clinical Nutrition, 14: 414419.

REINECCIUS, G A (1988). Spray drying in food flavours. Flavour Encapsulation (Reineccius, G A and Risch, S J eds.). Washington, DC, USA. p. 45.

RESHMA, M V, SARITHA, S S, BALACHANDRAN, C and ARUMUGHAN, C (2008). Lipase catalyzed interesterification of palm stearin and rice bran oil blends for preparation of zero trans shortening with bioactive phytochemicals. Bioresource Technology, 99: 5011-5019.

RICE, A L and BURNS, J B (2010). Moving from efficacy to effectiveness: red palm oil's role in preventing vitamin A deficiency. J. American College of Nutrition, 29: 302S-313S.

ROGERS, M A (2009). Novel structuring strategies for unsaturated fats - meeting the zero-trans, zerosaturated fat challenge: a review. Food Research International, 42: 747-753.

ROIAINI, M; ARDIANNIE, $\mathrm{T}$ and NORHAYATI, $H$ (2015). Physicochemical properties of canola oil, olive oil and palm olein blends. International Food Research J., 22: 1227-1233.

RUAN, X; ZHU, X M; XIONG, H; WANG, S Q; BAI, $\mathrm{C} Q$ and ZHAO, Q (2014). Characterisation of zerotrans margarine fats produced from camellia seed oil, palm stearin and coconut oil using enzymatic interesterification strategy. International. J. Food Science \& Technology, 49: 91-97.

SALMI YATI, S (2006). Low-fat chocolate spread based on palm oil. Palm Oil Developments No. 45: 2730

SAMBANTHAMURTHI, R; TAN, Y A; SUNDRAM, K; ABEYWARDENA, M; SAMBANDAN, T G; RHA, C; SINSKEY, A J; SUBRAMANIAM, K; LEOW, S S; HAYES, K C and WAHID, M B (2011). Oil 
palm vegetation liquor: a new source of phenolic bioactives. British J. Nutrition, 106: 1655-1663.

SCHOBER, J T (2009). Manufacture of glutenfree specialty breads and confectionery products. Gluten-free Food and Science Technology (Gallagher, E ed.). Blackwell Publishing Ltd, Oxford. p. 130-180.

SCIARINI, L S; RIBOTTA, P D; LEON, A E and PEREZ, G T (2012). Incorporation of several additives into gluten free breads: effect on dough properties and bread quality. J. Food Engineering, 111: 590-597.

SCIARINI, LS; VAN BOCKSTAEL, F; NUSANTORO, B; PÉREZ, G T and DEWETTINCK, K (2013). Properties of sugar-snap cookies as influenced by lauric-based shortenings. J. Cereal Science, 58: 234240.

SELLAMI, M; YUNUS, W M Z W; HARON, M J and RAHMAN, M Z A (2008). Enzymatic synthesis of fatty hydrazides from palm oils. J. Oleo Science, 57: 263-267.

SELLAMI, M; GHAMGUI, H; FRIKHA, F; GARGOURI, Y and MILED, N (2012). Enzymatic transesterification of palm stearin and olein blends to produce zero-trans margarine fat. $B M C$ Biotechnology, 12: 48.

SETYAWAN, AD; SUGIYARTO, S and SUSILOWATI, A (2013). Physical, physical chemistries, chemical and sensorial characteristics of the several fruits and vegetables chips produced by low-temperature of vacuum frying machine. Nusantara Bioscience, 5: 86103.

SHAMSI, K; MAN, Y C; YUSOFF, M S A and JINAP, $S$ (2002). A comparative study of dairy whipping cream and palm oil-based whipping cream in terms of FA composition and foam stability. J. Amer. Oil Chem. Soc., 79: 583-588.

SHAW, M (1984). Cheese substitutes: threat or opportunity? J. Society of Dairy Technology, 37: 27-31.

SIDDIQUI, S; AHSAN H; KHAN, M R and SIDDIQUI, W A (2013). Protective effects of tocotrienols against lipid-induced nephropathy in experimental type- 2 diabetic rats by modulation in TGF-beta expression. Toxicology and Applied Pharmacology, 273: 314-324.

SIDDIQUE, B M; AHMAD, A; IBRAHIM, M H; HENA, S; RAFATULLAH, $M$ and MOHD OMAR, A K (2010). Physico-chemical properties of blends of palm olein with other vegetable oils. Grasas $Y$ Aceites, 61: 423-429.
SMITH, R E J W; FINLEY, G A and LEVEILLE (1994). Overview of salatrim, a family of low calories fats. J. Agricultural and Food Chemical, 42: 432-434.

SMITH, K W (2012). Confectionery fats. Cocoa Butter and Related Compounds (Garti, N and Widlak, N R eds.). AOCS Press, Champaign, USA. p. 475-495.

SOARES, F A S D M; DA SILVA, R C; DA SILVA, K C G; LOURENÇO, M B; SOARES, D F and GIOIELLI, L A (2009). Effects of chemical interesterification on physicochemical properties of blends of palm stearin and palm olein. Food Research International, 42:1287-1294.

SOARES, F A S D M; DA SILVA, R C; HAZZAN, M; CAPACLA, I R; VICCOLA, E R; MARUYAMA, $\mathrm{J} M$ and GIOIELLI, L A (2012). Chemical interesterification of blends of palm stearin, coconut oil, and canola oil: physicochemical properties. J. Agricultural and Food Chemistry, 60: 1461-1469.

SOMMERBURG, O; DE SPIRT, S; MATTERN, A; JOACHIM, C; LANGHANS, C D; NESARETNAM, K; SIEMS, W; STAHL, W and MALL, M A (2015). Supplementation with red palm oil increases $\beta$-carotene and vitamin a blood levels in patients with cystic fibrosis. Mediators of Inflammation.

STUIJVENBERG, M E; FABER, M; DHANSAY, M A; LOMBARD, C J; VORSTER, N and BENADE, A J (2000). Red palm oil as a source of beta-carotene in a school biscuits used to address vitamin deficiency in primary school children. International J. Food Science and Nutrition, 51: S43-50.

SUNG, K K and GOFF, H D (2010.) Effect of solid fat content on structure in ice creams containing palm kernel oil and high-oleic sunflower oil. J. Food Science, 75: C274-C279).

SZCZESNIAK, A S (1997). Effect of storage on texture. Food Storage Stability (Irwin, A; Taub, R and Paul, S eds.). CRC Press, Florida, USA. p. 191-243.

TAN, S S; AMINAH, A; AFFANDI, M S; ATIL, O and BABJI, A S (2001). Chemical, physical and sensory properties of chicken frankfurters substituted with palm fats. International J. Food Sciences and Nutrition, 52: 91-98.

TAN, S S; AMINAH, A; ZHANG, X G and ABDUL, $S$ B (2006). Optimizing palm oil and palm stearin utilization for sensory and textural properties of chicken frankfurters. Meat Science, 72: 387-397.

TAN, H H (2016). Palm oil-based santan sawit posing as alternative to coconut milk. https://www. minimeinsights.com/2016/09/10/palm-oil-based- 
santan-sawit-posing-as-alternative-to-coconutmilk, accessed on 1 October 2017.

TAN, B and CHU, F L (1991). Effects of palm carotenoids on rat hepatic cytochrome $\mathrm{P} 450$ mediated benzopyrene metabolism. The American J. Clinical Nutrition, 53: 1071s-1075s.

TARMIZI, A H A and ISMAIL, R (2008). Comparison of the frying stability of standard palm olein and special quality palm olein. J. Amer. Oil Chem. Soc., 85: 245-251.

TARMIZI, A H A and ISMAIL, R (2014). Use of pilot plant scale continuous fryer to simulate industrial production of potato chips: thermal properties of palm olein blends under continuous frying conditions. Food Science \& Nutrition, 2: 28-38.

TARRAGO-TRANI, M T; PHILLIPS, K M; LEMAR, L E and HOLDEN, J M (2006). New and existing oils and fats used in products with reduced trans-fatty acid content. J. American Dietetic Association, 106: 867-880.

TIMMS, R E (2003). Confectionery Fats Handbook: Properties, Production and Application. The Oily Press, Bridgwater, England.

TOMARELLI, R M (1991). Randomized palm oil fat composition for infant formulas. US patent $5,000,975$.

TRABER, M G (2014). Vitamin E inadequacy in humans: causes and consequences. Advanced Nutrition, 5: 503-514.

TRACHOO, N (2002). Yogurt: the fermented milk. Songklanakarin J. Science and Technology, 24: 726-736.

TRAITLER, $\mathrm{H}$ and DIEFFENBACHER, A (1985). Palm oil and palm kernel oil in food products. J. Amer. Oil Chem. Soc., 62: 417-421.

TOWLER, C (1982). Cream products for the consumer. New Zealand J. Dairy Science and Technology, 17: 191-202.

UNDURRAGA, D; MARKOVITS, A and ERAZO, S (2001). Cocoa butter equivalent through enzymatic interesterification of palm mid fraction. Process Biochemistry, 36: 933-939.

US FOOD AND DRUG ADMINISTRATION (USFDA) (2017). Dietary supplements. https: / / www.fda.gov / downloads / Food / DietarySupplements / UCM240978.pdf, accessed on 2 October 2017.
VAN DAM, R M; STAMPFER, M; WILLE I I, W C; HU, F B and RIMM, E B (2002). Dietary fat and meat intake in relation to risk of type 2 diabetes in men. Diabetes Care, 25: 417-424.

VURAL, H and JAVIDIPOUR, I (2002). Replacement of beef fat in frankfurters by interesterified palm, cottonseed and olive oils. Eur. Food Res. Technol., 214: 465-468.

VOON, P T; MISKANDAR, M S; LIM, W H; LAI, O M, TAN, C P and LAI, W T (2013). A method for delivering lipophilic nutrients from red palm olein. Patent application No. WO2013077726A2. https: / / www.google.com / patents / WO2013077726A2?, accessed on 1 September 2017.

WALSTRA, P (1998). Secondary nucleation in triglyceride crystallisation. Progress in Colloid and Polymer Science, 108: 4-8.

WANG, Q; AFSHIN, A; YAKOOB, M Y; SINGH, G M; REHM, CD; KHATIBZADEH, S; MICHA, R; SHI, P; MOZAFFARIAN, D; EZZATI, M and FAHIMI, S (2016). Impact of nonoptimal intakes of saturated, polyunsaturated, and trans fat on global burdens of coronary heart disease. J. American Heart Association, 5: e002891.

WAN ROSNANI, A I; MAT SAHRI, M; RAMLI, M R; CHE HA, C M and IBRAHIM, A R (2015). Palmbased mayonnaise. MPOB Information Series No. 583. MPOB, Bangi.

WAN ROSNANI, A I; ABD HAMID, R; MAT SAHRI, $M$ and IBRAHIM, A R (2017). Palm mid fraction (PMF)-based fat in ice confection formulation. MPOB Information Series No. 622. MPOB, Bangi.

WAN ROSNANI, A I; NOR AINI, I and NOR AZMAN, I (2006). Palm-based whipped toppings. MPOB Information Series No. 324. MPOB, Bangi.

WARD, J (1998). Crystallisation of fats. Development in Oils and Fats (Garti, N and Sato, K eds.). Marcel Dekker, New York, USA. p. 189-226.

WEISS, T J (1983). Shortening - introduction. Food Oils and their Use (Weiss, T J ed.). AVI Publishing, Westport, USA. p. 121-129.

WONG, R S Y and RADHAKRISHNAN, A K (2012). Tocotrienol research: past into present. Nutrition Reviews, 70: 483-490.

XU, Z, JIN, J, ADHIKARI, P, LIANG, J, XU, X, LIU, $Y$ and WANG, $X$ (2016). Shea olein-based cold-soluble powder fats with medium-and longchain triacylglycerol: production via chemical 
interesterification using shea olein and palm kernel stearin. RSC Advances, 6: 18632-18640.

YANTY, N A M; MARIKKAR, J M N; MISKANDAR, M S; VAN BOCKSTAELE, F; DEWETTINCK, K and NUSANTORO, B P (2017). Compatibility of selected plant-based shortening as lard substitute: microstructure, polymorphic forms and textural properties. Grasas Y Aceites, 68: 1-6.

YOUNG, S L; SARDA, $\mathrm{X}$ and ROSENBERG, $\mathrm{M}$ (1993). Microencapsulating properties of whey proteins. 1. Microencapsulation of anhydrous milk fat. J. Dairy Science, 76: 2868.

YU, Z B; HAN, S P; ZHU, C; SUN, Q and GUO, X R (2009). Effects of infant formula containing palm oil on the nutrient absorption and defecation in infants: a meta-analysis. Chinese J. Pediatrics, 47: 904-910.

ZAIDA, Z; YUSOF, M S A; NOOR LIDA, H M D; MOHD NOR, O and BURHANUDDIN, A S (1997). Production and characterization of palm-based santan powder. PORIM Information Series No. 65. PORIM, Bangi.

ZAIDA, Z; SUID, A; WAN ROSNANI, A I; NOR AINI, I and AZMAN, I (2008). Palm-based transfree liquid santan. $M P O B$ Information Series No. 415. MPOB, Bangi.

ZAIDA, Z; MISKANDAR, M S; WAN ROSNANI AWG ISA and SUID ABDUL AZIZ (2016). Santan sawit plus. MPOB Information Series No. 733. MPOB, Bangi.

ZAIDA, Z; MISKANDAR, MS; ISA WAN ROSNANI AWG, NOR AINI IDRIS and AZMAN ISMAL (2013). Palm-based liquid coconut milk substitute. Patent application No. WO 2013077726 A2. https: / / www. google.com / patents / WO2013077726A2?cl=en, accessed on 1 October 2017.

ZALIHA, O; ELINA, H; MISKANDAR, M S; SITI HAZIRAH, M F; NOOR LIDA HABI, M D; MUHAMMAD RODDY, R and NORIZZAH, A R (2015a). Palm oil crystallisation: a review. J. Oil Palm Res. Vol. 27: 97-106.
ZALIHA, O; NORIZZAH A R; ZAIZUHANA, S and MARANGONI, A G (2015b). Fractal dimension in palm oil crystal networks during storage by image analysis and rheological measurements. LWT-Food Science and Technology, 64: 483-489.

ZEBA, A N; PREVEL, Y M; SOME, I T and DELISLE, $\mathrm{H} \mathrm{F}$ (2006). The positive impact of red palm oil in school meals on vitamin A status: study in Burkina Faso. Nutrition J., 5: 17-26.

ZEDDELMANN, H V and WURZIGER, J (1973). Verhalten und Beurteilung von Fritierfetten in der Praxis. Fette, Seifen, Anstrichmittel, 75: 18-24.

ZHANG, H;SMITH, P and ADLER-NISSEN, J (2004). Effects of degree of enzymatic interesterification on the physical properties of margarine fats: Solid fat content, crystallization behavior, crystal morphology, and crystal network. J. Agricultural and Food Chemistry, 52: 4423-4431.

ZION MARKET RESEARCH (2017). At 7.2\% CAGR, global palm oil market size \& share expected to reach \$92.84 Billion in 2021: ZMR. https: / / globenewswire. com / news-release / 2017 / 04 / 19 / 961940 / 0 / en / At-7-2-CAGR-Global-Palm-Oil-Market-Size-Shareexpected- to-reach-92-84-Billion-in-2021-ZMR.html, accessed on 3 September 2017.

ZOU, X Q; HUANG, J H; JIN, Q Z; LIU, Y F; SONG, Z and WANG, X G (2011). Lipase-catalyzed preparation of human milk fat substitutes from palm stearin in a solvent-free system. J. Agriculture and Food Chemistry, 59: 6055-6063.

ZOU, X Q; HUANG, J H; JIN, Q Z; LIU, Y F; SONG, Z and WANG, X G (2012a). Lipase-catalyzed synthesis of human milk fat substitutes from palm stearin in a continuous packed bed reactor. J. Amer. Oil Chem. Soc., 89: 1463-1472.

ZOU, X Q; HUANG, J H; JIN, Q Z; LIU, Y F; TAO, G J; CHEONG, L Z and WANG, X G (2012b). Preparation of human milk fat substitutes from palm stearin with arachidonic and docosahexaenoic acid: combination of enzymatic and physical methods. J. Agriculture and Food Chemistry, 60: 94159423. 